Accepted Manuscript

\title{
Journal of the Geological Society
}

\section{Palaeogeographic evolution of the Rattray Volcanic Province, Central North Sea}

\author{
Ailsa K. Quirie, Nick Schofield, David W. Jolley, Stuart G. Archer, Malcolm \\ J. Hole, Adrian Hartley, Douglas Watson, Roger Burgess, Jessica H. Pugsley, \\ John R. Underhill \& Simon P. Holford
}

DOI: https://doi.org/10.1144/jgs2019-182

Received 29 October 2019

Revised 29 January 2020

Accepted 14 February 2020

(C) 2020 The Author(s). Published by The Geological Society of London. All rights reserved. For permissions: http://www.geolsoc.org.uk/permissions. Publishing disclaimer:

www.geolsoc.org.uk/pub_ethics

Supplementary material at https://doi.org/10.6084/m9.figshare.c.4857195

To cite this article, please follow the guidance at

https://www.geolsoc.org.uk/ /media/Files/GSL/shared/pdfs/Publications/AuthorInfo_Text.pdf?la=en

\section{Manuscript version: Accepted Manuscript}

This is a PDF of an unedited manuscript that has been accepted for publication. The manuscript will undergo copyediting, typesetting and correction before it is published in its final form. Please note that during the production process errors may be discovered which could affect the content, and all legal disclaimers that apply to the journal pertain.

Although reasonable efforts have been made to obtain all necessary permissions from third parties to include their copyrighted content within this article, their full citation and copyright line may not be present in this Accepted Manuscript version. Before using any content from this article, please refer to the Version of Record once published for full citation and copyright details, as permissions may be required. 


\section{Palaeogeographic evolution of the Rattray Volcanic Province, Central North Sea}

Ailsa K. Quirie ${ }^{1,2 *}$, Nick Schofield', David W. Jolley', Stuart G. Archer³, Malcolm J. Hole', Adrian Hartley', Douglas Watson ${ }^{1,4}$, Roger Burgess ${ }^{1,5}$, Jessica H. Pugsley', John R. Underhill ${ }^{6}$ \& Simon P. Holford ${ }^{7}$

' Department of Geology and Petroleum Geology, University of Aberdeen, Aberdeen AB24 3UE, UK

${ }^{2}$ Present address: Shell International LTD, Shell Centre, London SEI 7NA, UK

${ }^{3}$ RPS Energy, Goldvale House, 27-4 I Church Street West, Woking, Surrey GU2 I 6DH, UK

${ }^{4}$ Present address: ExxonMobil International LTD, Ermyn House, Ermyn Way, Leatherhead, Surrey KT22 8UX, UK

${ }^{5}$ Present address: Petrostrat, Tan-y-Graig, Parc Caer Seion, Conwy LL32 8FA, UK

${ }^{6}$ Shell Centre for Exploration Geoscience, Applied Geoscience Unit, Institute of Petroleum Engineering, Heriot-Watt University, Edinburgh EHI4 4AS, UK

${ }^{7}$ University of Adelaide, Australian School of Petroleum, Adelaide, Australia

*Correspondence: ailsa.quirie@shell.com

\section{Abstract}

The Rattray Volcanics Member, at the triple junction of the North Sea rift, is here subdivided into two informal sub-members based on analysis of core, wireline and seismic data. The Lower and Upper Rattray Volcanics were emplaced during two distinct phases of volcanism separated by a sustained volcanic hiatus. The presence of hyaloclastite and abundant freshwater algae at the base of the Lower Rattray indicates large lakes were present in the area prior to the volcanism, possibly indicating that collapse of the regional Jurassic Central North Sea dome began prior to volcanism. Pulsed subsidence likely 
occurred through the duration of the volcanism with lacustrine conditions becoming reestablished during the mid-volcanic hiatus. Sediments were deposited across the Rattray Volcanic Province in fluvial systems and floodplain coal swamps after the final cessation of volcanism, with later marine transgression leading to drowning of the area in the Callovian to Oxfordian. In terms of hydrocarbon prospectivity, no evidence is currently found to confirm the presence of an intra-basaltic play analogous to the Rosebank Field in the FaroeShetland Basin, although post-volcanic Pentland Formation sedimentary sequences in the Fisher Bank Basin area indicates the possibility of supra-basaltic prospectivity in the triple junction.

\section{Introduction}

The Rattray Volcanic Province is an area of basaltic rocks at the triple junction of the North Sea rift system covering $\sim 7400 \mathrm{~km}^{2}$ and reaching a maximum thickness of $\sim 1.5 \mathrm{~km}$ (Quirie et al. 2019). The volcanics were erupted and emplaced during the Mid-Jurassic, c. I70-163.5 Ma (Howitt et al. 1975; Underhill 1998; Husmo et al. 2002), prior to the main phase of extension (Late Jurassic) responsible for the formation of the Viking Graben, Central Graben and Moray Firth rift basins (Fraser et al. 2002). The volcanic rocks are unconformably overlain by reservoir sandstones of Upper Jurassic age in the Outer Moray Firth (e.g. the Piper Formation) and by marine source rocks of the Kimmeridge Clay Formation in the Witch Ground Graben. The position of the volcanic succession beneath these important petroleum system intervals has resulted in them being encountered by $>200$ hydrocarbon exploration and appraisal wells, with an abundance of well data available through the volcanic sequence, including petrophysical logs, core and cuttings material. The volcanic rocks were first encountered by the Forties field discovery well $(21 / 10-1)$ in 1970 . Recent re-evaluation using 3D seismic data has established the Rattray Volcanics were likely 
erupted in a series of fissure eruptions from linear fissure systems and small associated volcanic edifices, including the major Buchan-Glenn Fissure System in the centre of the Rattray Volcanic Province (Quirie et al. 2019).

While recent work has clarified the likely eruption mechanism for the Mid-Jurassic volcanism, the precise tectonic and stratigraphic evolution of the North Sea triple junction area before, during and after the Mid-Jurassic volcanism is not well constrained. Regional uplift is suggested to have occurred during the latest Early Jurassic - early Mid-Jurassic (Underhill \& Partington 1993) followed by volcanism and later rifting during the Late Jurassic (Fraser et al. 2002). However, the precise timing of emplacement of the volcanics and their relationship to the background sedimentation is poorly understood. Very little detail has been published about the c. 8 million years between apparent domal uplift of the area in the Late Toarcian (c. I74.I Ma (Gradstein et al. 2012)) and the cessation of volcanism which likely occurred during the late Bathonian (c. 166.I Ma (Gradstein et al. 20I2)) in the Rattray Volcanic Province.

The large and disparate datasets (including seismic, petrophysical logs and palynology data) available in the Rattray Volcanics provide a rare and important opportunity to evaluate the evolution of a volcanic province at a triple junction. Outcrop studies in onshore triple junction volcanic provinces, e.g. the Afar Depression in East Africa (Barberi et al. 1972), allow detailed evaluation of the volcanic rocks in situ but is limited by exposure. In contrast, the abundance of seismic and well data through the Rattray Volcanics allows examination of the volcanic province at a gross scale, in three dimensions.

A detailed petrographic and geochemical understanding of cored lavas in individual boreholes has previously been established and possible implications discussed (Howitt et al. 1975; Gibb \& Kanaris-Sotiriou 1976; Woodhall \& Knox 1979; Dixon et al. 198I; Fall et al. 1982; Ritchie et al. 1988; Latin et al. 1990; Latin \& Waters 1992). However, no regional scale 
well correlation of volcanic lithologies has been constructed across the Rattray Volcanic Province and there exists no stratigraphic framework that systematically describes the lateral and vertical volcanic lithology distribution through the Rattray succession.

In this paper we present an integrated analysis of the Rattray Volcanic Province using core, petrophysical logs and 3D seismic reflection data to establish a lithostratigraphic framework for the volcanic sequence. We show that the Rattray Volcanics Member can be subdivided into two sub-members that were emplaced during two main phases of volcanism separated by an eruptive hiatus, during which the area underwent subsidence. The extrusive units that comprise the two main phases of volcanism are here named the Lower Rattray Volcanics and Upper Rattray Volcanics Members. Combining volcanic lithological analysis with palynological data from sedimentary interbeds we present a series of palaeogeographic diagrams representing the evolution of the Rattray Volcanic Province, providing fresh insight into the geological history of the triple junction area during the Mid-Jurassic.

\section{Geological Setting}

The North Sea is a continental rift basin with the main phase of extension occurring during the Late Jurassic (Fraser et al. 2002). The Rattray Volcanic Province is located across UK offshore Quads 15, 16, 21 and 22 at the rift triple junction where the Viking Graben, Central Graben and Outer Moray Firth Basin intersect (Fig. I). The triple junction area is comprised of a series of fault-bounded sub-basins and intra-basinal highs with the pre-rift volcanic rocks downthrown by $\sim 3 \mathrm{~km}$ in basinal areas by later faulting (Quirie et al. 2019).

The Rattray Volcanics Member (RVM) is part of the Mid-Jurassic Pentland Formation (Richards et al. 1993) with the volcanic rocks interbedded with mudstones, coals and sandstones around the fringes of the lava field (Fig. 2; Richards et al. 1993) indicating eruption in a fluvio-deltaic environment. The RVM was likely sourced in a series of effusive 
eruptions from fissures including the major Buchan-Glenn Fissure System, which is thought to have exploited the Highland Boundary Fault which developed during the Caledonian Orogeny in the Devonian Period, c. 220 million years prior to the Rattray eruptions (Quirie et al. 2019). The RVM is broadly coeval with the Ron Volcanics Member (Richards et al. 1993), located $\sim 150 \mathrm{~km}$ south in the West Central Graben, which is not considered further in this study.

\section{Data \& Methodology}

The main dataset used in this study is publicly released hydrocarbon exploration and appraisal well data from the UK Oil and Gas Database (CDA), now the National Data Repository (NDR). A variety of well data was used including cuttings, core, palynological data and petrophysical logs. 3D seismic reflection data were used to investigate the basinscale architecture of the volcanic province, and to indicate potential volcanic facies in areas with limited well control. We subdivide the Rattray Volcanic Province into five main areas, based on structural elements established during Late Jurassic rifting, to enable systematic interpretation of the volcanic facies in each region (Table I; Fig. 3).

There are 235 wells which encounter the RVM with I48 (63\%) drilled in the NW Area of the volcanic province (Tab. 2). The wells in the NW Area predominantly targeted Upper Jurassic Piper Formation sandstone reservoirs which unconformably overlie the volcanic succession. The RVM is also relatively thin ( $200-400$ m thick) in the NW Area, meaning that $4 \mathrm{I}$ wells ( $28 \%$ of NW Area wells) penetrate the base of the volcanic succession. In contrast, wells in the SW Area and SE Areas of the volcanic province targeted younger reservoirs, e.g. Paleocene sandstones of the Forties Field. As such, only 16 wells ( $10 \%$ of total Rattray well penetrations) are located in the SW and SE Areas of the volcanic province. Additionally, most wells that encountered the volcanic rocks in the SE and SW Areas ceased drilling 
within the volcanic succession and so do not penetrate the base of the Rattray sequence (only three base-Rattray well penetrations occurred). Consequently, uncertainty remains with regards to the palaeoenvironments and volcanic facies associated with the initiation of volcanism in the southern areas of the Rattray Volcanic Province.

\section{Core \& Cuttings}

Core and cuttings of the RVM were viewed at the British Geological Survey (BGS) core store in Keyworth with samples taken for preparation of thin sections. The cuttings available for the RVM are often closer to dust or coarse powder in consistency, rather than the typical small pieces of rock. As such, features such as the proportion of vesicles in the lava package (used to indicate whether lavas are tabular or a compound series of flows (Millett et al. 2014)) are not discernible from the cuttings examined in this study. The variability of colour of the cuttings was used as an indicator of the type of subaerial volcanic material present in the RVM: tabular lavas generally produce cuttings which are dark grey and dull, with very little colour variation. Compound lavas produce cuttings with more colour variation (Millett et al. 2014) due to the high proportion of crust in compound flows, which is generally more weathered and has a higher proportion of amygdales than dense flow cores. However, given the lack of discernible features in cuttings, subaerial lava facies were interpreted primarily using wireline signature.

\section{Petrophysical logs}

Mafic igneous lithologies produce characteristic wireline log signatures which can be used to indicate rock types in wells without core data (Planke 1994; Archer et al. 2005; Nelson et al. 2009; Watton et al. 20 I4; Millett et al. 2016; Watson et al. 20I7, 2019; Hardman et al. 20I8, 2019). Figure 4 shows examples of typical igneous wireline facies drilled in the Rattray 
Volcanic Province. Logs used for lithological interpretation of igneous rocks in this study include gamma ray, deep and micro-resistivity, density, neutron porosity, acoustic travel time, caliper and photoelectric factor, though in some wells only a partial log suite is available.

Basaltic material produces typically low gamma values (15-60 API) due to the low abundances of $\mathrm{U}$, Th and $\mathrm{K}$ in early crystallising minerals from mafic melts. Tabular lavas (individual flows comprised of singular cooling units) are characterised by blocky log motifs - often with asymmetrical bell-shaped profiles (Planke 1994; Fig. 4(i)) - with high resistivity (20-200 ohm.m), high density $\left(2.7-3.1 \mathrm{~g} . \mathrm{cm}^{-3}\right)$ and fast acoustic travel times $\left(40-60 \mu \mathrm{s} . \mathrm{ft}^{-1}\right.$ or 5. I-7.6 km.s $\mathrm{s}^{-1}$ ) (Fig. 4(i)). Compound lavas (multiple stacked thin lavas with a high proportion of crust) produce serrated log profiles with slightly lower average densities and acoustic travel times than tabular lavas due to the increased proportion of flow crust and alteration of thinner flow cores (Nelson et al. 2009; Millet et al. 20 I6; Fig. 4(ii)).

Hyaloclastite (Fig. 4(iii)) produces log profiles with lower density (2.2-2.6 g.cm $\left.{ }^{-3}\right)$ and resistivity $\left(\mathrm{I}-\mathrm{I} 0\right.$ ohm.m) and slower acoustic travel time $\left(80-100 \mu \mathrm{s} . \mathrm{ft}^{-1}\left(3.0-3.8 \mathrm{~km} . \mathrm{s}^{-1}\right)\right)$ than subaerial lavas, and high neutron porosity values (40-60 pu) due to clay-bound water in the diagenetic alteration products of volcanic glass (Planke 1994; Bartetzko et al. 2005; Watton et al. 20/4). Hyaloclastites can exhibit variable log character due to the inherent heterogeneity associated with rapid quenching of hot magma during interaction with water (Watton et al. 2013; Greenfield et al. 2019). Volcaniclastic sedimentary rocks (Fig. 4(iv)) have lower densities $\left(2.3-2.5 \mathrm{~g} . \mathrm{cm}^{-3}\right)$, resistivities $(\mathrm{I}-10 \mathrm{ohm} . \mathrm{m})$ and acoustic travel times $(60-80$ $\left.\mu \mathrm{s} . \mathrm{ft}^{-1}\left(5 . \mathrm{I}-3.8 \mathrm{~km} . \mathrm{s}^{-1}\right)\right)$ than subaerial lavas, exhibiting high neutron porosity due to the presence of clay-bound water, and display a wide density-neutron separation similar to that of shale (Watson et al. 2017). Hyaloclastite and volcaniclastic sedimentary rocks display significant overlap in rock properties such as density and acoustic travel time and as such 
distinguishing between these facies on wireline alone can be problematic. For the purposes of this study we have identified uniform units with thickness in the order of $>50 \mathrm{~m}$ as hyaloclastite given that large interbedded thicknesses of epiclastic volcanic sediment would take much longer to accumulate than hyaloclastite, and would likely undergo significantly more compaction during burial. It is therefore likely that the proportion of hyaloclastite in the Rattray Volcanic Province has been underestimated, with thinner hyaloclastite units included as generic volcaniclastic facies. Increased gamma ray signature can indicate increased sediment content (clay minerals) and non-mafic constituents, which can be helpful in identifying siliciclastic sedimentary units, although again, defining these units based on petrophysical characteristics alone without cuttings is challenging (Andersen et al. 2009).

Intrusions typically exhibit blocky log profiles with little variation through thin intrusions due to the relatively consistent distribution of minerals through the intrusive body (Nelson et al. 2009; Mark et al. 2018). Basaltic intrusions exhibit low gamma ray values and are very dense and acoustically fast $\left(5.5-5.6 \mathrm{~km} \cdot \mathrm{s}^{-1}\right)$ due to the crystalline groundmass and lack of porosity (Planke et al. 1999; Nelson et al. 2009). No large-scale intrusive sill complexes are observed on seismic data associated with the Rattray Volcanic Province (Quirie et al. 2019) and so while intrusions are present within the RVM (Fall et al. 1982; Richie et al. 1988; Quirie et al. 2019) the majority are sub-seismic scale. However, late-stage basaltic melt likely intruded into the existing basaltic lava pile (Quirie et al. 2019), with relatively thin basaltic intrusions likely indistinguishable from basaltic lava on seismic and wireline data. As such the proportion of intrusive material in the RVM is therefore likely underestimated.

Subsurface basaltic melts undergo crystalline fractionation with time, commonly resulting in later intrusions of more evolved mineralogical compositions (Bailey \& Schairer 1966; Kushiro 1979). The Rattray Volcanics are alkaline (Howitt et al. 1975; Woodhall \& 
Knox 1979; Gibb \& Kanaris-Sotiriou 1976; Dixon et al. 1981; Fall et al. 1982); as such fractionation of the same melt would produce trachytic and phonolitic late-stage melt compositions (Bailey \& Schairer 1966; Kushiro 1979; Fall et al. 1982). Evolved alkaline melts have higher proportions of K-bearing minerals such as potassium feldspar and hornblende compared to non-alkaline melts due to the low silica content and resulting low proportion of quartz (Pechnig et al. 2005). The presence of evolved alkaline intrusions within the basaltic volcanic succession would likely result in significant increase in baseline gamma ray values (Delpino \& Bermúdez 2009) - this is observed in the centre of the Rattray Volcanic Province in well 21/03b-3 (see Rattray Igneous Lithologies section). Evolved alkaline intrusions have lower proportions of dense mafic minerals (e.g. olivine and pyroxene) compared to their basaltic counterparts and exhibit correspondingly lower density values and can even display density-neutron overlap similar to a limestone (Mark et al. 2018).

\section{Palynological data}

Palynological data was collated from well documents including palynological reports, charts, logs and end of well reports from wells drilled throughout the 1970s to 1990s. No new samples were processed. The vintage of the palynological data meant that only limited quantitative data was ayailable for the Pentland Formation in the triple junction area, with the majority of the data set compiled being in the form of presence/absence matrices. Most of these data were recorded from cuttings samples and, rarely, side wall cores. Cavings from overlying strata are therefore potentially present in the data set; where obviously caved species were noted in reports, the species were disregarded. Because these well data sets were prepared over several decades by different analysts, a degree of taxonomic variability is present. To resolve this issue with the metadata set, individual species were collated into higher taxonomic groups: ferns, bryophytes, lycopsids, xerophytic 
gymnosperms, gymnosperms, cycads, conifers, acritarchs, dinocysts and other algae. In addition, some ostracods and foraminifera were recorded. The palynological data was subjected to principle component analysis, correspondence analysis and detrended correspondence analysis (for an overview of these methods see Hammer \& Harper 2007), however, because of the nature of the data set, no statistically significant results were obtained. An alternative approach using broad palynomorph ecogroups after Abbink et al. (2004) and Olivera et al. (2015) was used, in conjunction with the definition of petrophysical and seismic facies, to indicate broad palaeoenvironmental conditions during the development of the Rattray Volcanic Province. The absence of quantitative data meant that the grouping of different species into different palynomorph ecogroups is subjective and should be considered as a preliminary environmental model for the area.

\section{Seismic Data}

Two 3D seismic surveys were used in this study: the PGS 3D Central North Sea MegaSurveyPlus (MSP) and the PGS 3D North Sea MegaSurvey (MS) (Fig. 3), which cover the majority of the Rattray Volcanic Province. The previously defined western Central Area is not covered by either survey and thus the interpretation of the stratigraphy in this area is solely based on well control. The MSP and MS are displayed in the time domain and extend to $\sim 6-7$ s two-way travel time (TWT), with the heavily faulted Top Rattray surface mapped at depths ranging from 2-2.4 s TWT (c. 2.3-2.8 km) on fault block footwalls to 4.4-4.9 s TWT (c. 5.6-6.2 km) in downthrown grabens (Quirie et al. 2019). A downwards increase in acoustic impedance corresponds to a negative amplitude seismic reflection (displayed in blue) and a downwards decrease in acoustic impedance corresponds to a positive amplitude seismic reflection (displayed in red). 


\section{RESULTS}

\section{Palynology of the Pentland Formation in the triple junction area}

The palynological record of the Middle Jurassic Pentland Formation is dominated by terrestrial palynomorphs, with an abundance of fern spores, gymnosperm pollen (e.g. Conifers, Ginkgo-types and Cycads) and freshwater algae. The Pentland Formation in the Rattray area can be divided into two broad palynomorph ecogroups: Aquatic and Lowland Terrestrial. Examples of marginal marine palynomorphs are present in supra-basaltic Pentland Formation sedimentary units in the north of the Rattray Volcanic Province but are very rare within the volcanic succession. Table 3 shows a condensed summary of the taxa recorded in twenty-five wells; five in each defined area of the Rattray Volcanic Province. A full table containing the recorded Pentland Formation palynology in each of the 62 examined wells can be found in the supplementary material.

\section{Aquatic Environments}

The Aquatic palynomorph ecogroup is comprised of species representative of freshwater environments. Well $15 / 12-1$ in the far north of the NW Area of the Rattray Volcanic Province records the occurrence of the fresh to brackish water ostracods Darwinula incurve and Belekocytheridea punctate within the RVM. Numerous other wells in the NW Area contain abundant Botryococcus, a chlorophycean algae, in the volcanic succession (e.g. 15/06I, I5/I7-10, I5/I8-2, I5/I8b-3, I5/2I-4; Tab. 3). Chlorophycean algae such as Botryococcus occur in freshwater environments (Tappan 1980) in eutrophic standing water (e.g. Jolley et al. 2008). Chlorophycean algal blooms have been associated with episodes of volcanism due to the increase in available nutrients associated with volcanic ash deposits (Jolley et al. 2008). Occurrences of Botryococcus in the RVM are recorded within hyaloclastite deposits (see 
Rattray Igneous Lithologies section below), indicating lava progradation into a freshwater lacustrine environment rather than a fully marine embayment.

\section{Lowland Terrestrial Environments}

The Lowland palynomorph ecogroup comprises spores and pollen from a variety of fern, bryophyte (e.g. mosses), and lycopsid (e.g. clubmosses) spores, xerophytic gymnosperms, and gymnosperm families. Fern, bryophytes and lycopsid spores are indicative of plants which likely grew in relatively wet lowland environments (Abbink et al. 2004; Olivera et al. 20I5), e.g. fluvial floodplains or lake-side vegetation. Gymnosperm pollen are indicative of larger plants such as cycads, pines and araucarian conifers and were likely derived from upland areas or drier floodplain environments (Abbink et al. 2004). Gymnosperm pollen are easily transported by wind and water - when coupled with the variety of lowland spores found in the Pentland Formation their occurrence is probably indicative of transported pollen rather than in situ gymnosperm forests.

Lowland terrestrial palynomorphs are found in wells throughout the Rattray Volcanic Province (Tab. 3) indicating that the volcanics were erupted across a relatively wet lowland environment consisting of fluvial channels, associated floodplains and lakes. Drier upland areas were likely the site of larger forests, sourcing wind-transported gymnosperm pollen to be preserved in floodplain environments with lowland group palynomorphs.

\section{Marine Palynomorphs: isolated incursions and post-volcanic transgression}

Towards the northern fringes of the Rattray Volcanic Province in the NW Area and NE Area there are rare occurrences of marine palynomorphs within the Pentland Formation against a background of terrestrial sedimentation (Tab. 3). These marine palynomorphs (predominantly dinocysts e.g. Gonyaulacysta and Dichadogonyaulax) are restricted to thin 
horizons (e.g. a thin clay unit in 16/23-3 in the NE Area; sample 1402) and may represent short-lived marine incursions during instances of high relative sea level; marine conditions reached the Buchan area in the Callovian, likely from the Viking and Central Grabens (Davies et al. 1996), and a Late Bathonian transgression in the South Viking Graben is identified by Cockings et al. (1992). However, the paucity of marine palynomorphs sampled in the majority of the RVM indicates that during the deposition of the Pentland Formation ( Bajocian-Bathonian in this area) the depositional environment remained broadly terrestrial (Cockings et al. 1992; Richards et al. 1993).

Marine palynomorphs in association with Lowland Terrestrial palynomorphs are recorded in supra-volcanic siliciclastic Pentland Formation units in wells in the far north of the NW Area of the Rattray Volcanic Province (e.g. well 15/12-1 sample 20I; Tab. 3), likely indicating the initiation of transgression at the fringes of the lava field following the cessation of volcanism. However, supra-volcanic Pentland Formation palynomorphs in the majority of the volcanic province (e.g. 22/05b-4; 16/23-4) are assigned to the Lowland Terrestrial group with no marine palynomorphs recorded.

The few well penetrations in the southern areas of the Rattray Volcanic Province (Tab. 2) result in very limited palynological data for the Pentland Formation in this area. However, the supra-volcanic Pentland Formation in the SE Area is dominated by Lowland Terrestrial palynomorphs, which are interpreted to be indicative of post-volcanic drainage systems being established on the exposed volcanic landscape. The lack of marine taxa in available palynomorph data in the Pentland Formation in the south of the volcanic province compared to the northern areas indicates that the post-volcanic marine transgression may have progressed from north to south, although well data bias may be a factor. 


\section{Rattray Igneous Lithologies}

Using wireline and core data we identify three major igneous lithological associations within the RVM: subaerial volcanic rocks, subaqueous volcanic rocks and a minor intrusive suite. The subaerial group is composed of subaerial lavas, including tabular and compound lavas, and volcaniclastic sedimentary interbeds. The subaqueous group is comprised of basaltic hyaloclastite and reworked subaqueous volcanic material. The minor intrusive suite intrudes into the lava pile and underlying strata. Figure 5 shows the proportions of different igneous and sedimentary lithologies present in drilled Pentland Formation sequences across the Rattray Volcanic Province.

\section{Subaerial volcanic rocks: lavas and volcaniclastic sedimentary interbeds}

Subaerial basaltic lavas with interbedded volcaniclastic sedimentary rocks are found across the majority of the areal extent of the Rattray Volcanic Province (Fig. 5). Volcaniclastic rocks include both primary deposits (thin hyaloclastite units from interaction of lava with surface water, e.g. streams and ponds) and epiclastic deposits which have been reworked by surface processes (Fisher 1966). Tabular lavas are formed by high volume eruptions with fast effusion rates (Walker 1971). When erupted into areas of increased accommodation space, lava ponds in topographic lows and inflates with continued eruption, resulting in the formation of thick individual lava flows. Individual flows with thicknesses $>30 \mathrm{~m}$ are observed in the NW Area (well 15/24b-3; Fig. 4). Compound lavas are composed of multiple thin stacked flows (individual flow units $\sim 5 \mathrm{~cm}-5 \mathrm{~m}$ thick) and form when the effusion rate is lower (Walker 197I). The proportion of compound to tabular lavas increases distally to the source of volcanic eruptions (Nelson et al. 2009). The proportion of compound flows increases in the east of the Rattray Volcanic Province (Fig. 5). 
A core through the RVM in well $15 / 22-13$ contains examples of the different subaerial volcanic lithologies (Fig. 6). Examples of both aphyric and porphyritic lavas are drilled in close succession (Fig. 6(i) and (ii)). Both have a groundmass of pyroxene and plagioclase feldspar (the latter showing some degree of flow alignment (i)), and contain abundant opaque minerals, likely magnetite as reported by Howitt et al. (1975) and Fall et al. (1982). The porphyritic basalt in well I5/22-13 has large phenocrysts ( $2 \mathrm{~mm}$ across) of heavily altered olivine; the olivines are entirely replaced by secondary minerals. There are also large pyroxene phenocrysts $(\sim 2 \mathrm{~mm})$, which in the pictured sample are relatively fresh, but in other flows have also undergone pervasive secondary alteration. The presence of pyroxene and olivine phenocrysts without plagioclase phenocrysts indicates these porphyritic basalts may represent the ankaramites previously reported by Fall et al. (1982).

The 15/22-13 core also contains a series of basaltic clastic packages situated between subaerial lavas (Fig. 6). The basal $\sim 7 \mathrm{~m}$ of the core contains repeated fining-upwards reworked volcaniclastic (i.e. epiclastic (Fisher 1966; Millet et al. 2014)) packages. These include conglomerate with large (up to $10 \mathrm{~cm}$ across) rounded cobbles of different volcanic lithologies, including porphyritic and aphyric basalt with variably grey-green to purple-black groundmass, fining upwards into sandstone and siltstone. The two main fining-upwards packages are $\sim 2-3 \mathrm{~m}$ thick separated by a thin fining-upwards sequence $\sim 50 \mathrm{~cm}$ thick.

These repeated volcaniclastic fining-upwards sedimentary units are interpreted as being deposited in a fluvial system (e.g. Bridge \& Tye 2000) within the volcanic province during a hiatus in eruption (or at least during a time when lava did not reach this part of the province). The variety and rounded nature of the volcanic cobbles in the conglomerate indicates that the clasts are not always derived from the immediately adjacent volcanic strata, with prolonged transport in the fluvial system likely. The stacked channel system indicates these deposits represent a hiatus of sufficient time for a sustained fluvial system to 
be established, which can take several thousand years, compared to equivalent lava thicknesses which accumulate in decades (Hole et al. 2013). The individual fining upwards packages comprise stories that record minimum channel depths of 2-3 m, with channel belts likely in the order of <I-2 km in width (e.g. Gibling 2006).

The stacked fluvial channels are overlain by $a \sim 3 \mathrm{~m}$ thick unit of primary volcaniclastic rock (Fig. 6(iii)) which differs markedly from the fluvial conglomerates and sandstones. It has a dark red-brown fine-grained clay matrix with clasts of dark grey-black fine-grained basalt. The clasts vary in size from $\sim 1-30 \mathrm{~mm}$ and are either angular to subangular or have uneven clast edges, with the latter likely representing juyenile basalt clasts (primary magma clasts that solidify in situ, rather than being redeposited following reworking of existing volcanic rocks (Fisher \& Schmincke 2012)). There is a high proportion of a white pore-filling mineral, identified as calcite in thin section, infilling vesicles in basalt clasts and large areas of the matrix.

The presence of juvenile and fragmented basalt clasts, volcanic clay matrix and a high proportion of secondary pore-filling calcite leads to interpretation of this unit as a thin bed of hyaloclastite formed by lava being quenched and fragmented during contact with surface water. The volcanic clay matrix likely replaced primary volcanic glass that formed from rapid cooling of magma upon contact with water; volcanic glass alters very readily to clay minerals (Cerling et al. 1985). The pervasive pore-filling calcite indicates that the rock initially had relatively high porosity, likely due to fragmentation during interaction with the water. This cored sequence of fluvial sediment-hyaloclastite-subaerial lava (Fig. 6) is interpreted as having formed by lava flowing into a topographic low occupied by a fluvial system. 


\section{Subaqueous volcanic rocks: hyaloclastite}

Hyaloclastite forms when magma is quenched during interaction with water (Honnorez \& Kirst 1975; Watton et al. 2014). Rattray hyaloclastite generally displays higher density, acoustic velocity and resistivity, and more homogeneous wireline log profiles than the volcaniclastic sedimentary packages. The presence of hyaloclastite in the Rattray Volcanics is inferred from wireline and seismic character. Although the subaerial volcanic rocks group (discussed above) has thin $(\sim 3 \mathrm{~m})$ individual hyaloclastite units interbedded with subaerial lavas (Fig. 6(iii)), the subaqueous group comprises thick units of hyaloclastite $(>50-100 \mathrm{~m}$ thick) forming correlatable units across the Rattray Volcanic Province. This thickness of the hyaloclastite indicates that substantial volumes of lava flowed into a long-lived standing body of water. Basaltic hyaloclastite packages have been drilled in the NW and Central Areas (Fig. 5). In the SW Area few wells penetrate to any great depth within the RVM, and so the total extent of hyaloclastite is uncertain. In wells penetrating the base of the RVM succession (e.g. I5/2I-3 and I5/23-IZ) hyaloclastite forms the lowest extrusive volcanic lithology of the RVM, i.e. implying the presence of a standing water body pre-dating the onset of volcanism.

Seismic line A-A from north to south across the Buchan-Glenn Horst at the western end of the Buchan Glenn Fissure System shows a distinct lateral seismic character change within the Rattray Volcanics (Fig. 7). The seismic reflections in the centre of the horst near the fissure are laterally continuous and horizontal, and change laterally into thick packages ( $0.6 \mathrm{~s}$ TWT thickness; $\sim 1.6 \mathrm{~km})$ of inclined seismic reflections dipping northwards and southwards. The bright, laterally continuous reflections in the centre of the horst are interpreted as subaerial tabular lavas (drilled nearby in well $2 \mathrm{I} / 03 \mathrm{~b}-3$ ). The inclined reflections are interpreted as foresets of hyaloclastite deltas from lava that prograded northwards and southwards from the subaerial fissure system into two adjacent bodies of water, forcing the lakes backwards. Inclined seismic reflections are traceable across $\sim 200$ 
$\mathrm{km}^{2}$ of the SW Area. Hyaloclastite is drilled in multiple wells across the NW Area covering $\sim 1800 \mathrm{~km}^{2}$.

\section{Intrusions}

This group represents a minor suite of evolved igneous intrusions that were emplaced into both the existing lava succession and underlying strata. Quirie et al. (2019) investigated the volcanic province on seismic data and found no evidence of large-scale intrusive complexes on seismic data. The intrusions, described here from core data from well $21 / 03 b-3$, crosscut pre-existing Rattray lavas. The intrusions generally range from $<10 \mathrm{~cm}$ to $\sim 5 \mathrm{~m}$ thick and have undergone extensive alteration. As the majority are centimetre-scale they are typically not thick enough to be identifiable on either seismic data or petrophysical logs (Schofield et al. 2017; Mark et al. 2018). The intrusions are composed of alkali feldspar, mica and nepheline (Fig. 8). The thickest evolved intrusion drilled in the Rattray Volcanic Province (well $15 / 23 a-8$ ) is $\sim 50$ m thick (Fig. 4). It produces extremely high gamma ray values (I90220 API) likely due to the high proportion of potassium in the alkali feldspar, and the high uranium and thorium content in nepheline. The intrusion is less dense than the surrounding basaltic material $\left(\sim 2.5-2.6 \mathrm{~g} . \mathrm{cm}^{-3}\right)$, which, combined with the low neutron values associated with crystalline material due to the lack of porosity, produces a density-neutron wireline overlap similar to that of limestone.

The alkali feldspar, mica and nepheline mineralogy is indicative of nepheline syenites, which form by fractional crystallisation of silica-undersaturated alkali basalts (Delpino \& Bermúdez 2009). The mineralogy and the cross-cutting relationship of the intrusions compared to the basalts indicates that this intrusive phase was likely a minor late-stage event that was not associated with the main phase of lava eruption. The intrusions are therefore interpreted to represent the emplacement of the residual melt during the latter 
stages of magmatism (e.g. similar to the syenites associated with the alkali dolerite boss from Cnoc Rhaonastil in Islay (Hole \& Morrison 1992)).

\section{Lithostratigraphic framework of the Rattray Volcanic Province}

Using the volcanic lithology scheme described above, the RVM is subdivided into two main lithostratigraphic sequences representing two distinct phases of eruption: the Lower RVM ('Lower Rattray') and Upper RVM ('Upper Rattray') (Fig. 2), separated by a mid-volcanic hiatus in eruption which is represented by the accumulation of volcaniclastic sedimentary rocks, tentatively identified in wells across the width of the Rattray Yolcanic Province. Figure 9 shows a correlation panel of the wells containing the two distinct eruptive sequences in the Rattray Volcanic Province. The differentiation between the Lower Rattray and Upper Rattray is typified in well 15/2I-3 in the NW Area (Fig. 9).

The base of the Pentland Formation in $15 / 2 /-3$ is composed of shales, silts tones and volcaniclastic sedimentary rocks $\sim 21 \mathrm{~m}$ thick, representing the immediate pre-volcanic environment. Above this basal sedimentary unit is a $\sim 70 \mathrm{~m}$ thick hyaloclastite sequence, overlain by subaerial lavas and interbeds. This hyaloclastite to subaerial lava sequence is interpreted as having been emplaced during the first phase of volcanism forming the Lower Rattray. The hyaloclastite is interpreted to have formed by lava erupting into a lake (indicated by the presence of freshwater algae Botryococcus in nearby hyaloclastite e.g. I5/2I4), with subaerial lavas eventually prograding over the hyaloclastite as the lake was in-filled by volcanic material.

A $\sim 17 \mathrm{~m}$ thick volcaniclastic sedimentary unit overlies the subaerial lavas of the Lower Rattray in I5/2I-3. This volcaniclastic unit is interpreted as having formed from the erosion and redeposition of Lower Rattray volcanic rocks during a hiatus in eruption. MidRattray volcaniclastic units are drilled, and can be correlated, across the Rattray Volcanic 
Province (Fig. 9) indicating this unit likely represents a prolonged hiatus in magmatism across the volcanic province rather than being localised to the area of well $15 / 2 I-3$.

The volcaniclastic sedimentary unit representing the mid-volcanic hiatus in eruption in I5/21-3 is overlain by a $\sim 65 \mathrm{~m}$ thick hyaloclastite succession, which is in turn capped by subaerial lavas. This second hyaloclastite to subaerial sequence is interpreted as having been emplaced during a separate, second phase of volcanism, forming the Upper Rattray. The presence of hyaloclastite at the base of the Upper Rattray sequence indicates that lacustrine conditions were re-established on the volcanic landscape during the mid-volcanic hiatus, likely indicative of continued basin subsidence between the first and second eruptive phases.

The Lower Rattray and Upper Rattray are also tentatively interpreted in wells without hyaloclastite (e.g. $21 / 03 b-3$ and 22/05b-4), based on the presence of mid-volcanic sedimentary units and the proportion of compound and tabular lavas. A volcaniclastic sedimentary bed is interpreted as being representative of the mid-volcanic hiatus in $21 / 03 \mathrm{~b}-$ 3 (Fig. 9). Immediately beneath the mid-volcanic hiatus is a package of compound lavas. Compound lava flows are associated with a slower flow rate than tabular flows (Walker 197I). The presence of a thick series of compound lavas overlying tabular lavas may indicate changes in volumetric flow rate associated with the end of the first phase of volcanism at the top of the Lower Rattray. A $\sim 20$ m thick volcaniclastic sedimentary unit is interpreted as representing the mid-volcanic hiatus in well 22/05b-4 (Fig. 9). The presence of tabular lavas overlying the mid-volcanic hiatus in wells $2 \mathrm{l} / 03 \mathrm{~b}-3$ and $22 / 05 \mathrm{~b}-4$ is interpreted as possibly representative of the renewed pulse of magmatism associated with the initiation of the second phase of volcanism emplacing the Upper Rattray Volcanics. 


\section{Discussion}

\section{Duration of Mid-Jurassic volcanism}

The precise age and duration of the Rattray volcanic eruptions is unknown, with $\mathrm{K}-\mathrm{Ar}$ and Ar-Ar radiometric dating (e.g. Howitt et al. 1975; Ritchie et al. 1988) having produced ages which contradicts biostratigraphic ages of sedimentary interbeds on the current stratigraphic timescale (Gradstein et al. 2012), e.g. approximate magmatic ages of $153 \pm 4 \mathrm{Ma}$

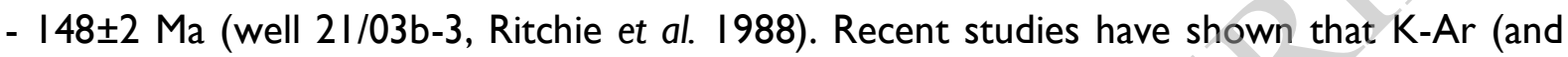
increasingly Ar-Ar) dating of basaltic rocks is considered as relatively unreliable compared to other stratigraphic age evidence (Jolley 2009; Schofield et al. 2017; Wilkinson et al. 2017). The stratigraphic position of the Rattray Volcanics indicates eruption during the MidJurassic, likely at some point during the Bajocian-Bathonian based on the palynology of the interbedded sedimentary rocks, or possibly into the Callovian (c. I70-I63.5 Ma; Howitt et al. 1975; Underhill 1998; Husmo et al. 2002). However, we suggest the lack of volcanic strata in preserved Callovian sequences around the fringes of the Rattray Volcanic Province indicates the volcanics were likely erupted within the Bajocian-Bathonian (I70.3-I66.I Ma; Gradstein et al. 20(2)).

Based on the eruptive durations of other continental flood basalt provinces, it is extremely unlikely that the volcanism lasted the entire duration of this 4.2 -million-year window. In the Deccan Traps, $\sim 10,000,000 \mathrm{~km}^{3}$ of volcanic rocks were erupted in only c. 4 million years $\left(2,500 \mathrm{~km}^{3}\right.$ per 1000 years) (Jerram \& Widdowson 2005) and the main phase of the Columbia River Flood Basalt Province erupted $\sim 220,000 \mathrm{~km}^{3}$ of basalt in 1.6 million years (I $40 \mathrm{~km}^{3}$ per 1000 years) (Hooper et al. 2007). The Grande Ronde Basalt lavas form $\sim 66 \%$ of the total volume of the Columbia River Basalt Group, with $150,000 \mathrm{~km}^{3}$ erupted in c. 420,000 years $\left(360 \mathrm{~km}^{3}\right.$ per 1000 years) (Barry et al. 2010$)$. 
An approximate eruption volume of $\sim 3000 \mathrm{~km}^{3}$ is calculated for the Rattray Volcanic Province from the areas of the thickness contours in Fig. I(b). By comparison with the eruption rates during the main phase of the Columbia River Flood Basalts, $3000 \mathrm{~km}^{3}$ of lava could be erupted in c. 8,000-22,000 years. Since the Rattray Volcanic Province is orders of magnitude smaller than large continental flood basalt provinces such as Columbia River, extrapolation of flood volcanism duration from larger provinces to the Rattray Volcanic Province must be treated with caution. However, it is likely that discrete pulses of the Lower Rattray and Upper Rattray lava sequences were erupted over timescales of 10,000s100,000 s of years during the Bajocian-Bathonian in the Mid-Jurassic, rather than millions of years as previously suggested in the Central North Sea (e.g. Richards et al. 1993). However, the length of the major mid-volcanic hiatus - and any other unidentified intra-volcanic hiatuses - and therefore the total duration of the volcanism is unknown. This uncertainty highlights the need for detailed re-assessment of the Middle Jurassic stratigraphy of the Central North Sea.

\section{Palaeogeographic evolution of the Rattray Volcanic Province}

Based on the palynological data from the Pentland Formation, in conjunction with wireline and seismic facies analysis, we present an interpretation of the palaeogeographic evolution of the Rattray Volcanic Province in a series of gross depositional environment cartoons.

\section{Pre-Mid Jurassic}

Investigation of the Mid-Jurassic subcrop lithologies in wells which contain Pentland Formation strata shows that the Fladen Ground Spur and Buchan-Glenn Horst areas had the oldest exposed subcrop preserved before the eruption of the RVM, with Permian, Carboniferous and Devonian rocks exposed (Fig. 10, 21/03b-3). The lack of Triassic strata 
on these current intra-basinal highs, either through non-deposition or complete erosion of Triassic sediments, indicates the structures were relative high points prior to the eruption of the RVM. The Fladen Ground Spur likely formed a positive structure throughout the Jurassic (Boldy \& Brealey 1990). The NW, Central, SE Areas have Triassic sedimentary rocks present beneath the Middle Jurassic (Fig. 10). Triassic strata in the west of the Rattray Volcanic Province predominantly comprise red claystone of the Lower Triassic Smith Bank Formation, whereas the Triassic subcrop in the east of the Rattray area is dominated by sandstones of the Middle and Upper Triassic Skagerrak Formation. Several wells in the far east of the Rattray area have thin Liassic (Lower Jurassic-uppermost Triassic) sedimentary units beneath the Middle Jurassic (Fig. 10, 16/23-2).

The eastwards-younging progression of pre-Rattray strata from Lower Triassic in the west to Middle and Upper Triassic to Lower Jurassic in the far east of the Rattray area indicates that the uplift and erosion of the crust was not centred on the Rattray Volcanic Province as has previously been inferred (Underhill \& Partington 1993), but rather that the west side of the area underwent greater uplift and erosion than the eastern side.

\section{Early Mid-Jurassic: palaeotopography}

The variety and proportion of spores and pollen species found in the Pentland Formation can be used in conjunction with sedimentary facies to indicate the possible presence of upland and lowland areas during volcanism. For example, the RVM in Blocks 15/17 and 15/I 8 rarely has more than one species of gymnosperm pollen recorded but contains multiple species of fern spores in addition to freshwater Botryococcus, which indicates that this area was distal to the upland source of gymnosperm pollen. In contrast, the RVM in Blocks 15/24 and 15/30 (close to the Fladen Ground Spur) contain numerous species of gymnosperm pollen and fewer species of fern spores (e.g. well I5/30-I contains 6 species of 
gymnosperms and 3 species of ferns). This may indicate that this area was more proximal to the upland area sourcing the gymnosperm pollen. The combination of older pre-Rattray subcrop on the Fladen Ground Spur and the inferred proximity to upland flora leads us to interpret that the Fladen Ground Spur was likely a low-relief topographic spur with flora dominated by gymnosperm (e.g. conifer forests) during the eruption of the RVM.

A second low-relief intra-basinal high - the proto-Buchan-Glenn Horst - is proposed to have been present trending WSW-ENE in the Central area (Fig. II). The presence of Carboniferous-Permian subcrop to the Middle Jurassic strata indicates that erosion (or nondeposition) of Triassic strata occurred on the Buchan-Glenn Horst prior to the Middle Jurassic; it is therefore interpreted as being subaerially exposed during the early Middle Jurassic. Additionally, the presence of subaerial basaltic tabular lavas at the base of the RVM in nearby well I5/26a-2 and the subaerial lava seismic facies present across the horst (Fig. 7) indicates subaerial exposure of the Buchan-Glenn Horst during volcanism.

Early Middle Jurassic: sedimentation $(T=0)$

Mapping of sedimentary facies in the basal $\sim 30 \mathrm{~m}$ section of the Middle Jurassic Pentland Formation allows the construction of the early Middle Jurassic pre-volcanic palaeoenvironment in this area of the Rattray Volcanic Province (Fig. II, T=0). Pentland Formation siliciclastic sedimentary rocks including mudstones and coal have been drilled beneath the RVM in the NW Area (Fig. I0), with the pre-Rattray Pentland Formation containing terrestrial palynomorphs including gymnosperm pollen and fern spores. Prior to the onset of volcanism, the presence of a large lake (with a surface area of $\sim 1,800 \mathrm{~km}^{2}$ ) is interpreted in the NW Area (Fig. II, T=0) from the areal extent of wells which contain hyaloclastite at the base of the Lower Rattray. A second smaller lake is interpreted in the SW Area just to the south of the Buchan-Glenn Horst intra-basinal high (Fig. I I, T=0); the 
surface area of this lake $\left(\sim 200 \mathrm{~km}^{2}\right)$ is constrained from the extent of hyaloclastite foresets in the RVM observed in seismic data.

The NE Area was likely the site of a fluvial system, with sandstones and mudstones drilled at the base of the Pentland Formation containing terrestrial lowland group palynomorphs (e.g. 16/23-4). The fluvial system in the NE Area likely flowed northwards up the proto-South Viking Graben from the lake towards the coast; the younger sections of the Pentland Formation and the overlying Callovian age Hugin Formation in the NE Area contain marine palynomorphs indicating a southward-progressing marine incursion in the ?Late Bathonian-Callovian as the Brent delta was transgressed.

The lowermost Pentland Formation facies in the south of the SE Area comprises volcaniclastic deposits. We suggest this area was relatively flat and at a slightly higher elevation than the NW and SW Areas and therefore underwent limited deposition during the earliest Middle Jurassic. The Pentland Formation in this area contains lowland ecogroup palynomorphs including fern spores and gymnosperm pollen. We speculate the SE Area could have been the site of a fluvial system feeding northwest-wards into the two lake bodies. The SW Area of the Rattray Volcanic Province has no wells that penetrate through to the base of the volcanic succession and as such the nature of the Early Middle Jurassic palaeoenvironment in this area is unknown.

Eruption of Lower Rattray Volcanics $(T=I)$

The first phase of volcanism (Fig. II, T=I) emplaced the rocks of the Lower Rattray. The onset of volcanism is marked by the appearance of volcaniclastic sediments in the lacustrine deposits in the NW Area (e.g. 15/2I-3), with blooms of Botryococcus algae in nearby wells likely exploiting the increase of nutrients in the water (Jolley et al. 2008). The volcanism was presumably sourced from the Buchan-Glenn Fissure System (BGFS) (Quirie et al. 2019) in 
the southern Central Area of the volcanic province (Fig. II, T=I). The fissure likely opened during the earliest onset of extension in the Rattray area (Quirie et al. 2019). Lava effused primarily from the BGFS but other source areas are probable, e.g. the Renee Ridge (Stewart 1999) and the Forties Montrose High (Quirie et al. 2019). The lava flowed away from the BGFS northwards and southwards into the low areas occupied by lakes, forming thick prograding hyaloclastite to eventually subaerial sequences (Fig. II, T=I).

The northwards-prograding lava reached the southern parts of the NE Area (e.g. 16/23-2). However, the vast majority of the Pentland Formation in this area during $T=I$ comprises volcaniclastic deposits; it is likely that erosion and re-working of primary volcanic material and possible primary ash-fall deposits from the eruptions dominated deposition in the NE Area. The SE Area was distal to the fissure system; the first phase of volcanism emplacing the Lower Rattray in this part of the study area is dominated by compound lavas and volcaniclastic sedimentary units with rare thin tabular lavas (Fig. 9, 22/05b-4). While the RVM comprises interbedded volcaniclastic and siliciclastic sedimentary units in the NE Area (discussed in Mid-Rattray hiatus below), we have not identified clear evidence of transport of 'clean' siliciclastic sediments into the lava field during eruption. Based on our lithological interpretations, the majority of intra-volcanic sedimentation was likely the result of erosion and reworking of volcanic sequences. In terms of hydrocarbon prospectivity, we have not yet identified an obvious analogue to the intra-basaltic Colsay play of the Rosebank Field (Schofield \& Jolley 2013; Hardman et al. 2018) in the Rattray Volcanic Province.

Mid-Rattray hiatus in eruption ( $T=2)$

The energy of the first phase of eruption dissipated, with the decrease in volume and rate of magma effusion recorded by a change from tabular to compound lavas at the top of the Lower Rattray in well 2I/03b-3, situated close to the BGFS (Fig. 9). Lacustrine conditions 
were re-established in the NW Area due to continued subsidence in the basin (Fig. II, T=2). The limited well data in the SW Area means identifying the different phases of volcanism in the south is challenging, however well $21 / 02-2$ drilled hyaloclastite towards the top of the RVM, i.e. likely in the Upper Rattray, close to the southward-prograding hyaloclastite foresets (Fig. 5). We therefore suggest that subsidence also re-established the lacustrine conditions in the SW Area. The locations of the renewed lakes likely suggests that the NW, Central and SW Areas saw greater subsidence than the NE and SE Areas of the volcanic province. During the hiatus in eruption the fluvial system in the NE Area was dominated by siliciclastic sedimentation, resulting in the deposition of Pentland Formation sandstones over the earlier volcaniclastic sedimentary rocks (e.g. 16/23-4). The SE Area has limited well control and the subdivision into the two phases of volcanism is uncertain, but we suggest that the hiatus is likely represented by a thick volcaniclastic sedimentary unit in well $22 / 05 \mathrm{~b}$ 4 (Fig. 9), as the overlying tabular lavas may indicate the renewed volcanism of the second phase.

Eruption of Upper Rattray Volcanics ( $T=3)$

Renewed magmatism resulted in the second phase of volcanism which emplaced the Upper Rattray, consisting of another hyaloclastite to subaerial lava flow sequence in the NW Area (Fig. II, T=3). The lavas in the NW Area comprise thick, inflated tabular flows (>30 m thick), indicating ponding and inflation of flows in regions of increased accommodation space (Lyle 2000). Conversely, the whole Upper Rattray sequence in the SE Area is relatively thin ( 70 m) and is composed of sparse tabular and compound lavas with a high proportion of volcaniclastic sedimentary rocks. Wells in the far south of the SW Area penetrate stacked sequences of compound and tabular lavas and volcaniclastic sediments in the Upper Rattray succession, however the individual tabular lavas are relatively thin $(\sim 3-7 \mathrm{~m}$ in $2 \mathrm{I} / 10-\mathrm{I})$. The 
lava thicknesses and morphologies suggest the far south of the SW and SE Areas of the volcanic province likely formed within a relatively flat subaerial environment with limited accommodation space, hindering inflation of lava flows, in comparison to those in the NW Area. In the NE Area a fining-upwards volcaniclastic package above the mid-volcanic siliciclastic units in well 16/23-4 is interpreted as re-working of volcanic material in a fluvial system rather than primary volcaniclastic deposits from explosive eruptions. The distribution and thicknesses of lavas in the Upper Rattray indicates the majority of lava emplacement in the second phase of volcanism was focussed towards the NW, Central and SW Areas of the volcanic province. Well $2 \mathrm{I} / 03 \mathrm{~b}-3$ is close to the source of the magmatism and contains nephenline syenite intruding the Lower Rattray sequence as seen in Fig. 8, and given the erratic and higher gamma values, possibly also in the Upper Rattray, although this is not confirmed by core. These intrusions likely occurred during the later stages of the second phase of volcanism as the evolved residual melts intruded into the volcanic sequence.

Post-volcanic drainage systems $(T=4)$

Following cessation of volcanism in the Late Middle Jurassic, drainage systems were established on the volcanic landscape (Fig. II, T=4). Thick packages of sandstone, coal, siltstone and shale $(\sim 100-290 \mathrm{~m})$ are present above the RVM in the SE Area (e.g. 22/05b-4 and 22/02-2). Thin Pentland Formation siliciclastic deposits are also present above the volcanic rocks in the NW and SW Areas (e.g. 2 I/I5b-4). The presence of Pentland Formation siliciclastic sedimentary rocks above the volcanic rocks in well $21 / 02-1$ indicates that postvolcanic fluvial sedimentation also occurred in the Central Area. However, the upper boundary of the Rattray Volcanics is unconformable across most of the volcanic province (Fig. 10; Boldy \& Brealey 1990). Erosion of Upper Jurassic and uppermost Middle Jurassic 
rocks, likely associated with the Late Jurassic rifting event e.g. in the Central Area, resulted in the volcanic stratigraphy being unconformably overlain by Upper Jurassic and Cretaceous sedimentary rocks (Fig. 10). While it is possible that the Central Area may have remained upstanding for longer after volcanism had ceased, we suggest that the post-volcanic fluvial systems likely formed across the majority of the Rattray Volcanic Province, with subsequent footwall uplift during Late Jurassic rifting causing erosion of post-volcanic fluvial deposits.

\section{The North Sea Dome: Implications for tectonic development of the triple junction}

The tectonic evolution of the North Sea rift triple junction area through the Jurassic is complex. Marine sediments were deposited in a shallow sea during the Early Jurassic (Husmo et al. 2002). During the late Early Jurassic to earliest Mid-Jurassic (Toarcian to Aalenian, c. 182-170 Ma) the whole of the Central North Sea area is thought to have undergone regional domal uplift (Hallam \& Sellwood 1976; Eynon 198I; Ziegler 1990; Underhill \& Partington 1993, 1994) driven by a short-lived thermal anomaly centred on the area of the Rattray Volcanic Province at the present-day triple junction, preceding the eruption of the RVM (Fig. 12) (Underhill \& Partington 1993). The uplift is thought to have caused emergence and erosion of the Lower Jurassic and uppermost Triassic sedimentary rocks in the area (Underhill \& Partington 1993, 1994).

The dome is proposed to have affected an area of $\sim 1000 \mathrm{~km}$ in diameter (Underhill \& Partington 1993) based on the age of the subcrop to the Intra-Aalenian unconformity, with the area of greatest uplift in a circular to elliptical region centred on what subsequently became the triple junction during the Late Jurassic (Underhill \& Partington 1993). This area, which extends from the Ross Field in the west (Moray Firth) to east of the Rattray Volcanic Province in the Norwegian Sector, was likely a low-lying paralic region with erosion keeping pace with uplift (Underhill \& Partington 1993). 
Discounting the palaeo-highs of the Fladen Ground Spur and Buchan-Glenn Horst during the Mid-Jurassic, the eastwards-younging of the Intra-Aalenian unconformity subcrop in the Rattray Volcanic Province from early Triassic to lowermost Jurassic (Fig. 10) may indicate that the volcanics were erupted on the eastern flank of the dome. It is possible that peak uplift occurred to the west of the Rattray Volcanic Province in the Halibut/Ross granite area of the Moray Firth, which has been suggested as a high point between the Inner and Outer Moray Firth Basins during coeval Pentland Formation and Brora Coal Formation sedimentation (Davies et al. 1996).

The regional uplift reached its maximum lateral extent during the Aalenian, with deflation of the dome margins beginning in the Late Aalenian-Early Bajocian (c. I70 Ma (Gradstein et al. 2012)) as recorded by progressive marine onlap in the proto-rift arms such as the Viking Graben and Inner Moray Firth (Underhill \& Partington 1993, 1994). While prevolcanic subsidence in the centre of the dome was considered possible (Underhill \& Partington 1993, 1994), a lack of evidence for subsidence in the centre of the dome implied that the Rattray Volcanics were erupted during continued (contemporaneous) uplift of the dome centre (in the Bathonian to Early Callovian; Underhill \& Partington 1993). The dome margins - several hundreds of kilometres away - were suggested to be undergoing subsidence during this time (Underhill \& Partington 1993) (Fig. 12). The deflation of the dome centre was hypothesised to have begun in the late Callovian following the eruption of the Rattray Volcanics (Underhill \& Partington 1993).

However, our analysis of the sub-volcanic Pentland Formation facies indicates the area of the Rattray Volcanic Province (around Quads 15, 16, 21 and 22) was undergoing sediment deposition in large lakes during the Mid-Jurassic prior to, and indeed throughout, the eruption of the Rattray Volcanics. Lakes can form at high elevation (e.g. Lake Victoria in East Africa), however we suggest that the re-establishment of lacustrine conditions during 
the eruptive hiatus indicates the area undergoing either pulsed or continuous subsidence during the volcanic episode. The observed hyaloclastite to subaerial successions of both the Lower Rattray and Upper Rattray sequences indicate similar depositional settings for each. We therefore suggest that the subsidence of the proto-Rattray area likely began before the onset of volcanism (Fig. 12) with the initiation of extension. The presence of lacustrine sediments beneath the volcanic rocks, the occurrence of hyaloclastite at the base of the volcanic sequence, and the re-establishment of lacustrine conditions during the mid-volcanic hiatus indicates the area of the Rattray Volcanic Province was likely undergoing subsidence prior to and during the volcanic eruptions, although we cannot say with certainty whether the subsidence was continuous or pulsed during the volcanism (Fig. I2).

It is important to consider the scale of regional uplift compared to localised tectonic subsidence when discussing pre-volcanic uplift (Jerram \& Widdowson 2005), as localised subsidence in regionally uplifted areas can result in volcanism occurring across a variety of environments including subaqueous settings (Jerram \& Widdowson 2005). However, as deflation of the dome margins is proposed to have begun during the Late Aalenian-Early Bajocian (Underhill \& Partington 1993), c. 170 Ma (Gradstein et al. 2012), we suggest that the presence of a large lacustrine environment in the Rattray area prior to volcanism indicates that subsidence was also occurring at this stage in this area.

The onset of subsidence of the uplifted crust prior to volcanism in this case study of the Rattray Volcanics may have implications for the geodynamic relationships between uplift, subsidence, volcanism and extension in other modern-day volcanic rift settings, where examination of pre-volcanic subcrop is not necessarily possible. 


\section{Implications for prospectivity in the triple junction area}

The inferred presence of non-intruded sedimentary sequences beneath the Rattray Volcanic Province and the implications for hydrocarbon prospectivity was highlighted by Quirie et al. (2019). While the potential existence of sub-basaltic hydrocarbon plays is not discussed further in this paper, our re-evaluation of the stratigraphy of the Rattray Volcanic Province has implications for both intra- and supra-basaltic prospectivity in the triple junction area.

The Rosebank Field in the Faroe-Shetland Basin comprises reservoir-seal pairs of Paleocene-Eocene fluvial-marginal marine sandstones interbedded with basaltic lavas (Duncan et al. 2009; Schofield \& Jolley 2013; Hardman et al. 2018). The success of the Rosebank play is in part due to the fluvial deposits comprising clean clastic sediments sourced from outside the lava field. Volcanic activity associated with the opening of the North Atlantic (Naylor et al. 1999; Passey \& Jolley 2009) to the west resulted in lavas flowing south-eastwards towards the Faroe-Shetland Basin. The interfingering sandstones were deposited during extended periods of volcanic quiescence in large fluvial systems flowing from the south-west across the volcanic landscape (Schofield \& Jolley 20I3; Hardman et al. 2018). The oblique interface of the lavas and the fluvial systems created the successful intra-volcanic play fairway.

Our re-evaluation of the Rattray Volcanic Province has not identified clear evidence of an extensive analogous intra-basaltic play in the triple junction area. The interfingering sedimentary units in the wells analysed are predominantly volcaniclastic silts and clays derived from erosion and redeposition of the Lower Rattray Volcanics during the midvolcanic hiatus - rather than siliciclastic sandstones brought into the volcanic province in external drainage systems - likely resulting in poor intra-volcanic reservoir potential. Volcaniclastic units derived from erosion of in situ lavas have previously been highlighted as a risk to prospectivity in the Rosebank area (Schofield \& Jolley 20I3). 
Based on our study the most likely area for any intra-volcanic reservoir sandstones in the Rattray Volcanic Province is in the South Viking Graben. The $\sim$ Bajocian-Bathonian sequence in well 16/23-4 comprises a volcaniclastic Lower Rattray Volcanics sequence, overlain by siliciclastic sandstones deposited in the mid-volcanic hiatus, capped by further volcaniclastic sedimentary rocks forming the Upper Rattray Volcanics. However, while the transgressive Callovian-aged sandstones in the same well are oil-bearing, the underlying Bajocian-Bathonian Rattray Volcanics contain no oil shows, and only minor gas shows. While several wells in the South Viking Graben contain oil and gas shows in non-volcanic BajocianBathonian sedimentary successions, including small hydrocarbon accumulations (e.g. $\sim 5 \mathrm{~m}$ net pay column in 16/23-3 Bajocian-Bathonian sandstones), we find no evidence suggestive of a large-scale intra-volcanic hydrocarbon play in this area.

The juxtaposition of the Rattray Volcanics with Kimmeridge Clay source rock occurs in the Central Area where the Kimmeridge Clay Fm is downthrown in the Witch Ground Graben adjacent to the uplifted volcanic succession on the Renee Ridge. The RVM on the Renee Ridge contains oil and gas shows (e.g. I5/29-I), and - given the identification of a mid-volcanic hiatus with the potential for fluvial systems being re-established during this time - the Renee Ridge area may be worthy of further study should an appetite for exploration of an intra-basaltic play arise in future.

The Pentland Formation is a proven reservoir in the Central Graben, although less prolific than overlying transgressive sequences such as the Oxfordian Fulmar Formation (Jeremiah \& Nicholson 1999; Wilkinson et al. 2014). Given the reservoir potential of the Pentland Formation elsewhere in the Central North Sea, and the small hydrocarbon accumulations in the Bajocian-Bathonian and overlying Callovian sedimentary successions in the South Viking Graben, the post-volcanic Pentland Formation in the Rattray Volcanic Province may be worth investigating for untapped hydrocarbon prospectivity. The presence 
of substantial post-volcanic Bajocian-Bathonian Pentland Formation deposits on the terraces surrounding the Fisher Bank Basin (e.g. wells 22/05b-4 and 22/02-2) indicates the possibility of a supra-basaltic hydrocarbon play in the Fisher Bank Basin, and perhaps elsewhere in the triple junction area.

\section{Conclusions}

We have constructed a lithostratigraphic scheme for the Rattray Volcanics and illustrated the lateral variation in the proportions of volcanic lithologies across the Rattray Volcanic Province. The Rattray Volcanics Member of the Pentland Formation is dominated by basaltic lavas, interbedded volcaniclastic sedimentary units and basaltic hyaloclastite. A minor intrusive suite intrudes the base of the lava sequence.

The Rattray Volcanics were erupted in a broadly terrestrial environment with subaqueous hyaloclastites formed from lava flowing into large lakes. Volcanism resulted in hyaloclastite deltas prograding and eventually infilling the lakes.

The lavas were erupted in two phases of volcanism resulting in emplacement of the Lower and Upper Rattray Volcanics Members, separated by a hiatus between volcanic episodes during which the area underwent subsidence. Subsidence likely continued throughout the eruption of the Rattray Volcanics, re-establishing lacustrine conditions during the mid-volcanic hiatus. After the cessation of the second phase of volcanism fluvial systems were established across the volcanic landscape.

The presence of lacustrine deposits and hyaloclastite at the base of the Rattray Volcanics indicates the area was a sedimentary depocentre prior to the volcanic eruptions, rather than undergoing continued doming and uplift during volcanism. Subsidence of the North Sea dome in the area of the triple junction likely began before the eruption of the Rattray Volcanics, rather than post-volcanism. 
In terms of hydrocarbon prospectivity, the intra-volcanic sedimentary rocks are predominantly volcaniclastic sediments derived from erosion and redeposition of the in situ lavas, and would likely be of poor reservoir quality. The identification of a mid-volcanic hiatus indicates potential for intra-volcanic fluvial systems to have deposited reservoir sandstones, but no clear evidence is found of an existing intra-basaltic play based on the well penetrations examined in this study. However, a supra-basaltic Pentland reservoir play in the Fisher Bank Basin may be worthy of further investigation.

\section{Acknowledgements}

PGS are thanked for the donation of MegaSurveyPlus and MegaSurvey 3D seismic datasets to this $\mathrm{PhD}$ project. The British Geological Survey are thanked for the visit to the Keyworth core store and the loan of cuttings and core samples. John Millett and an anonymous reviewer are thanked for their detailed and helpful reviews which greatly improved the manuscript.

\section{Funding}

This work forms part of AQ's PhD research, which is funded by a scholarship from the Carnegie Trust for the Universities of Scotland. AQ thanks the Carnegie Trust for their support. 


\section{References}

Abbink, O.A., Van Konijnenburg-Van Cittert \& Visscher, H. 2004. A sporomorph ecogroup model for the Northwest European Jurassic - Lower Cretaceous: concepts and framework. Netherlands Journal of Geosciences/Geologie en Mijnbouw. 83(I), I7-38.

Andersen, M.S., Boldreel, L.O., White, R.S., Bais, G., Worthington, M., Shaw, F., Petersen, U.K., Jaspen, P., Waagstein, R. \& Mavko, G., 2009. Log responses in basalt successions in 8 wells from the Faroe-Shetland channel-A classification scheme for interpretation of geophysical logs and case studies. In: Varming, T. \& Ziska, H. (eds) Faroe Islands Exploration Conference: Proceedings of the 2nd Conference. Annales Societatis Scientiarum Færoensis, Supplementum, 50, 364-391.

Archer, S.G., Bergman, S.C., Iliffe, J., Murphy, C.M. \& Thornton, M. 2005. Palaeogene igneous rocks reveal new insights into the geodynamic evolution and petroleum potential of the Rockall Trough, NE Atlantic Margin. Basin Research, I7, I7I-20I.

Bailey, D.K. and Schairer, J.F., 1966. The System Na2O- Al2O3- Fc2O3- SiO2 at I Atmosphere, and the Petrogenesis of Alkaline Rocks. Journal of Petrology, 7(I), PP.II4-I 70.

Barberi, F., Tazieff, H. \& Varet, J. 1972. Volcanism in the Afar depression: Its tectonic and magmatic significance. Tectonophysics. I 5 (I-2), p. 19-29.

Barry, T.L., Self, S., Kelley, S.P., Reidel, S., Hooper, P. \& Widdowson, M. 20I 0. New ${ }^{40} \mathrm{Ar} /{ }^{39} \mathrm{Ar}$ dating of the Grande Ronde Basalt lavas, Columbia River Basalts, USA: Implications for duration of flood basalt eruption episodes. Lithos. I I 8. 213-222.

Bartetzko, A., Delius, H. \& Pechnig, R. 2005. Effect of compositional and structural variations on log responses of igneous and metamorphic rocks. I: mafic rocks Harvey, In: P. K., Brewer, T. S., Pezard, P. A. \& Petrov, V. A. (eds). Petrophysical Properties of Crystalline Rocks. Geological Society Special Publications., 240, 255-278.

Bridge, J.S. \& Tye, R.S. 2000. Interpreting the Dimensions of Ancient Fluivial Channel Bars, Channels, and Channels Belts from Wireline-Logs and Cores. AAPG Bulletin. 84(8), I205-। 228.

Cerling, T.E., Brown, F.H. \& Bowman, J.R. 1985. Low-temperature alteration of volcanic glass: Hydration, $\mathrm{Na}, \mathrm{K},{ }^{18} \mathrm{O}$ and $\mathrm{Ar}$ mobility. Chemical Geology: Isotope Geoscience section. 52(3-4), $281-293$.

Delpino, D.H. \& Bermúdez, A.M., 2009. Petroleum systems including unconventional reservoirs in intrusive igneous rocks (sills and laccoliths). The Leading Edge, 28(7), 804-8II.

Dixon, J.E., Fitton, J.G. \& Frost, R.T.C. 198I. The Tectonic Significance of PostCarboniferous Igneous Activity in the North Sea Basin. In: Illing, L. V. \& Hobson, G. D. (eds): Petroleum Geology of the Continental Shelf of North-West Europe. London, Institute of Petroleum, I2I-137.

Duncan, L., Helland-Hansen, D. \& Dennehy, C. 2009. The Rosebank Discovery, A new play type in intra basalt reservoirs of the North Atlantic volcanic province. In: $6^{\text {th }}$ European Production and Development Conference and Exhibition (DEVEX), Abstracts. Chevron Upstream Europe, Aberdeen, http://www.devexconference.org/pdf/Presentations 2009/2A 1605\%20Chevron\%20The\%20Rosebank\%20 Discovery\%20\%20new\%20play\%20type\%20in\%20intra\%20basalt\%20reservoirs\%20of\%20the\%20North \%20Atlantic\%20volcanic\%20province.pdf

Eynon, G. 198I. Basin Development and Sedimentation in the Middle Jurassic of the Northern North Sea. In: Illing, L. V. \& Hobson, G. D. (eds) Petroleum Geology of the 
Continental Shelf of North-West Europe. London, Institute of Petroleum, 196-204.

Fall, H.G., Gibb, F.G.F. \& Kanaris-Sotiriou, R. 1982. Jurassic volcanic rocks of the northern North Sea. Journal of the Geological Society of London, 139, 277-292.

Fisher, R. V. 1966. Rocks composed of volcanic fragments and their classification. EarthScience Reviews. I, 287-298.

Fisher, R. V., \& Schmincke, H. U. (20I2). Pyroclastic rocks. Springer Science \& Business Media. Springer-Verlag, Berlin, Heidelberg.

Fraser, S.I., Robinson, A.M., Johnson, H.D., Underhill, J.R., Kadolsky, D.G.A., Connell, R., Johannessen, P. and Ravnås, R. 2002. Upper Jurassic. In: Evans, D., Graham, C., Armour, A. \& Bathurst, P. (eds) The Millennium Atlas: Petroleum Geology of the Central and Northern North Sea. London, The Geological Society of London, I57-189.

Gibb, F.G.F. \& Kanaris-Sotiriou, R. 1976. Jurassic igneous rocks of the Forties Field. Nature, 260, 23-25.

Gibling, M.R. 2006. Width and thickness of fluvial channel bodies and valley fills in the geological record: a literature compilation and classification. Journal of Sedimentary Research. 76. 731-770.

Greenfield, L., Millet, J.M., Howell, J., Jerram, D.A., Watton, T., Healy, D., Hole, M.J., Planke, S. 2019. The 3D facies architecture and petrophysical properties of hyaloclastite delta deposits: An integrated photogrammetry and petrophysical study from southern Iceland. Basin Research. https://doi.org//0.1III/bre.12415

Gradstein, F.M., Ogg, J.G., Schmitz, M. \& Ogg, G. 2012. The Geologic Time Scale 2012. Elsevier B.V.

Hallam, A. \& Sellwood, B.W. 1976. Middle Mesozoic Sedimentation in Relation to Tectonics in the British Area. Journal of Geology, 84, 302-321.

Hammer, Ø. \& Harper, D.A.T. 2007. Paleontological Data Analysis. John Wiley \& Sons.

Hardman, J., Schofield, N., Jolley, D., Hartley, A., Holford, S. \& Watson, D. 20I8. Controls on the distribution of volcanism and intra-basaltic sediments in the CamboRosebank region, West of Shetland. Petroleum Geoscience, petgeo2017-06I.

Hardman, J.P.A., Holford, S.P., Schofield, N., Bunch, M. \& Gibbons, D. 2019. The Warnie volcanic province: Jurassic intraplate volcanism in Central Australia. Gondwana Research, 76, 322-347.

Haq, B.U. 2018. Jurassic sea-level variations: a reappraisal. GSA Today. 28(I), 4-I0.

Hole, M.J., Jolley, D.W., Hartley, A., Leleu, S., John, N. \& Ball, M. 2013. Lava-sediment interactions in an Old Red Sandstone basin, NE Scotland. Journal of the Geological Society, London. 170, 64I-655.

Honnorez, J. \& Kirst, P. 1975. Submarine basaltic volcanism: morphometric parameters for discriminating hyaloclastites and hyalotuffs. Bulletin Volcanologique. 39(3). 44I.

Hole, M.J. \& Morrison, M.A. 1992. The differentiated dolerite boss, Cnoc Rhaonastil, Islay: a natural experiment in the low pressure differentiation of an alkali olivine-basalt magma. Scottish Journal of Geology. 28, 55-69.

Howitt, F., Aston, E.R. \& Jacqué, M. 1975. The Occurrence of Jurassic Volcanics in the North Sea. In: Woodland, A.W. (ed) Petroleum and the Continental Shelf of Northwest Europe, Applied Science, Barking. 379-387.

Husmo, T., Hamar, G.P., Hoiland, O., Johannessen, E.P., Romuld, A., Spencer, A.M. \& Titterton, R. 2002. Lower and Middle Jurassic. In: Evans, D., Graham, C., Armour, A. \& Bathurst, P. (eds) The Millennium Atlas: Petroleum Geology of the Central and Northern North Sea. London, The Geological Society of London, I29-I 55.

Kushiro, I., 1979. Fractional crystallization of basaltic magma. The Evolution of the Igneous Rocks: Fiftieth Anniversary Perspectives, I7I-203. 
Jeremiah, J.M. \& Nicholson, P.H. 1999. Middle Oxfordian to Volgian sequence stratigraphy of the Greater Shearwater area. In: Fleet, A. J. \& Boldy, S. A R. (eds) Petroleum Geology of Northwest Europe: Proceedings of the 5th Conference, 153-170. (C) Petroleum Geology '86 Ltd. Published by the Geological Society, London.

Jerram, D.A. \& Widdowson, M. 2005. The anatomy of Continental Flood Basalt Provinces: geological constraints on the processes and products of flood volcanism. Lithos. 79. 385-405.

Jolley, D.W. 1997. Palaeosurface palynofloras of the Skye lava field and the age of the British Tertiary volcanic province. In: Widdowson, M. (ed.) 1997. Palaeosurfaces: Recognition, Reconstruction and Palaeoenvironmental Interpretation. Geological Society Special Publications. I20, 67-94.

Jolley, D.W., Widdowson, M. \& Self, S. 2008. Volcanogenic nutrient fluxes and plant ecosystems in large igneous provinces: an example from the Columbia River Basalt Group. Journal of the Geological Society, London. 165, 955-966.

Latin, D.M., Dixon, J.E. \& Fitton, J.G. 1990. Rift-related magmatism in the North Sea Basin. In: Blundell, D. J. \& Gibbs, A. D. (eds) Tectonic Evolution of the North Sea Rifts. Oxford, Oxford Science Publications, I0I-I44.

Latin, D. \& Waters, F.G. 1992. Basaltic magmatism in the North Sea and its relationship to lithospheric extension. Tectonophysics, 208, 77-90.

Lyle, P. 2000. The eruption environment of multi-tiered columnar basalt lava flows. Journal of the Geological Society. I 57, 7I 5-722.

Mark, N.J., Schofield, N., Pugliese, S., Watson, D., Holford, S., Muirhead, D., Brown, R. \& Healy, D. 2018. Igneous intrusions in the Faroe Shetland Basin and their implications for hydrocarbon exploration; new insights from well and seismic data. Marine and Petroleum Geology. 92, 733-753.

Millett, J.M., Hole, M.J. \& Jolley, D.W. 2014. A fresh approach to ditch cutting analysis as an aid to exploration in areas affected by large igneous province (LIP) volcanism. In: Cannon, S.J.C. \& Ellis, D. (eds). 2014. Hydrocarbon Exploration to Exploitation West of Shetlands. Geological Society, London, Special Publications, 397, 193-207.

Millett, J.M., Hole, M.J., Jolley, D.W., Schofield, N. \& Campbell, E. 2016. Frontier exploration and the North Atlantic Igneous Province: new insights from a $2.6 \mathrm{~km}$ offshore volcanic sequence in the NE Faroe-Shetland Basin. Journal of the Geological Society, I73, 320-336.

Nelson, C.E., Jerram, D.A. \& Hobbs, R.W. 2009. Flood basalt facies from borehole data: implications for prospectivity and volcanology in volcanic rifted margins. Petroleum Geoscience, 15, 313-324.

Olivera, D.E., Zavattieri, A.M. \& Quattrocchio, M.E. 20I5. The palynology of the Canadon Asfalto Formation (Jurassic), Cerro Condor depocentre, Canadon Asfalto Basin, Patagonia, Argentina: Palaeoecology and palaeoclimate based on ecogroup analysis. Palynology. 39(3), 362-386.

Planke, S. 1994. Geophysical response of flood basalts from analysis of wire line logs: Ocean Drilling Program Site 642. Vøring volcanic margin. Journal of Geophysical Research, 99(B5), 9279-9296.

Planke, S., Alvestad, E. and Eldholm, O. 1999. Seismic characteristics of basaltic extrusive and intrusive rocks. The Leading Edge, I 8(3), 342-348.

Quirie, A.K., Schofield, N., Hartley, A., Hole, M.J., Archer, S.G., Underhill, J.R., Watson, D. \& Holford, S. 2019. The Rattray Volcanics: Mid-Jurassic fissure volcanism in the UK Central North Sea. Journal of the Geological Society, I 76, 462-48I.

Richards, P.C., Lott, G.K., Johnson, H., Knox, R.W.O'B. \& Riding, J.B. 1993. 3. Jurassic of the Central and Northern North Sea. In: Knox, R. W. O'B. \& Cordey, W. G. (eds) 
Lithostratigraphic Nomenclature of the UK North Sea. Nottingham, British Geological Survey.

Ritchie, J.D., Swallow, J.L., Mitchell, J.G. \& Morton, A.C. 1988. Jurassic ages from intrusives and extrusives within the Forties Igneous Province. Scottish Journal of Geology, 24, 8I88.

Schofield, N. \& Jolley, D.W. 2013. Development of intra-basaltic lava-field drainage systems within the Faroe-Shetland Basin. Petroleum Geoscience, 19, 273-288.

Schofield, N., Holford, S.P. Millett, J., Brown, D.J., Jolley, D.W., Passey, S.R., Muirhead, D., Grove, C., Magee, C., Murray, J., Hole, M., Jackson, C.A.-L. \& Stevenson, C. 2017. Regional magma plumbing and emplacement mechanisms of the Faroe-Shetland Sill Complex: implications for magma transport and petroleum systems within sedimentary basins. Basin Research. 29, 4I-63.

Tappan, H. 1980. The Paleobiology of Plant Protists. W.H. Freeman, San Francisco, CA.

Underhill, J.R. 1998. Jurassic. In: Glennie, K. W. (ed.) Petroleum Geology of the North Sea: Basic Concepts and Recent Advances. Blackwell Science, 245-293.

Underhill, J.R. \& Partington, M.A. 1993. Jurassic thermal doming and deflation in the North Sea: implications of the sequence stratigraphic evidence. In: Parker, J. R. (ed.) Petroleum Geology of Northwest Europe: Proceedings of the 4th Conference. London, The Geological Society, 337-345.

Underhill, J.R. \& Partington, M.A. 1994. Use of genetic sequence stratigraphy in defining and determining a regional tectonic control on the mid-Cimmerian Unconformity: Implications for North Sea Basin development and the global sea-level chart: In: Weimer, P. and Posamentier, H. W. (eds) Siliciclastic sequence stratigraphy: American Association of Petroleum Geologists Memoir, 58, 449-484.

Walker, G.P.L. 197I. Compound and simple lava flows and flood basalts. Bulletin Volcanologique, 35, 579-590.

Watson, D., Schofield, N., Jolley, D., Archer, S., Finlay, A.J., Mark, N., Hardman, J. \& Watton, T. 2017. Stratigraphic overview of Palaeogene tuffs in the Faroe - Shetland Basin, NE Atlantic Margin. Journal of the Geological Society, I 74, 627-645.

Watson, D., Holford, S., Schofield, N., Mark, N. 2019. Failure to predict igneous rocks encountered during exploration of sedimentary basins: A case study of the Bass Basin, Southeastern Australia. Marine and Petroleum Geology. B, 526-547.

Watton, T.J., Jerram, D.A., Thordarson, T. \& Davies, R.J. 20 I3. Three-dimensional lithofacies variations in hyaloclastite deposits. Journal of Volcanology and Geothermal Research. 250, 19-33.

Watton, T.J., Wright, K.A., Jerram, D.A. \& Brown, R.J. 20I4. The petrophysical and petrographical properties of hyaloclastite deposits: Implications for petroleum exploration. AAPG Bulletin, 98, 449-463.

Wilkinson, M., Stuart Haszeldine, R., Morton, A. \& Fallick, A.E. 2014. Deep burial dissolution of K-feldspars in a fluvial sandstone, Pentland Formation, UK Central North Sea. Journal of the Geological Society, London, I 7 I, 635-647.

Wilkinson, C.M., Ganerød, M., Hendriks, B.W.H. \& Eide, E.A. 2017. Compilation and appraisal of geochronological data from the North Atlantic Igneous Province (NAIP). Geological Society, London, Special Publications, 447 (I), 69-103.

Woodhall, D. \& Knox, R.W.O'B. 1979. Mesozoic volcanism in the northern North Sea and adjacent areas. Bulletin of the Geological Survey of Great Britain, 70, 34-56.

Ziegler, P.A. 1990. Geological Atlas of Western and Central Europe, 2nd Edition. London, Geological Society for Shell International Petroleum Maatschappij B.V., The Hague. 
Fig. I. (a) Location of Central North Sea in NW Europe, Google Earth. (b) Position of the Rattray Volcanic Province at the triple junction of the North Sea rift system where the Viking Graben, Central Graben and Outer Moray Firth Basin intersect. After Fraser et al. 2002. (c) Present day thickness map of the Rattray Volcanics Member (RVM) of the Pentland Formation with the position of the Buchan-Glenn Fissure System highlighted; after Quirie et al. 2019, structures after Fraser et al. 2002. (d) Inset of Buchan-Glenn Fissure System identified on spectral decomposition of the top-Rattray seismic surface, after Quirie et al. 2019.

Fig. 2. Stratigraphic column for the triple junction area of the Central North Sea (after Quirie et al. 2019). In this paper the RVM of the Middle Jurassic Pentland Formation is subdivided into two informal sub-members, the Lower Rattray Volcanics and the Upper Rattray Volcanics, based on wireline interpretation of the drilled volcanic lithologies.

Fig. 3. (a) Map of the Rattray Volcanic Province split into five areas in this study: NW Area, NE Area, Central Area, SW Area, and SE Area based on structures formed during post-volcanic rifting (see Table I). Also highlighted are the seismic surveys used in this study: MS, PGS 3D North Sea MegaSurvey; MSP, PGS 3D Central North Sea MegaSurveyPlus. After Quirie et al. 2019. Position of seismic line shown in Figure 7 highlighted in yellow. Also shown are the positions of key wells mentioned in this study. (b) Polarity of seismic line shown in Figure 7 (after Quirie et al. 2019). A downwards increase in acoustic impedance coincides with a negative amplitude reflection, shown in blue.

Fig. 4. Composite log of drilled Rattray lithologies in wells I6/27a-3, I5/23a-8 and I5/24b-3 showing typical examples of the igneous lithologies present in the RVM.

Fig. 5. Proportion of Pentland Formation facies in drilled sequences across the Rattray Volcanic Province, calculated from wireline data. N.B. Intrusive rocks are not included as a separate proportion as they are very minor; intrusions in $21 / 03 \mathrm{~b}-3$ are included in the tabular lava component which they intrude.

Fig. 6. Examples of volcanic rocks found in the RVM from core samples in well $15 / 22-13$. (i) Thin sections of porphyritic basalt with phenocrysts of olivine and pyroxene. (ii) Thin sections of aphyric basalt. (iii) Thin unit ( $\sim 3 \mathrm{~m}$ thick) of hyaloclastite beneath basaltic lava flow. (iv) Volcaniclastic siltstone, grading downwards into (v) volcaniclastic conglomerate. Fining upwards sedimentary units capped by thin hyaloclastite then subaerial lavas indicates this sequence likely represents lava flowing into an active fluvial system.

Fig. 7. Seismic facies of the RVM across the Buchan-Glenn Fissure System on the BuchanGlenn Horst. (I) Laterally continuous seismic reflections indicative of subaerial lavas. (2) Inclined seismic reflections on either side of the subaerial flows are probably representative of two hyaloclastite deltas created by lava foresets prograding into standing water bodies from the subaerial fissure system between them.

Fig. 8. (a) Core and (b) thin section of intrusive nepheline syenite from well $21 / 03 b-3$. The intrusions cross-cut lavas in the centre of the volcanic province near the Buchan-Glenn Fissure System. This cross-cutting relationship, in addition to the composition of the 
intrusions (see text), indicates they likely formed during a minor intrusive event of residual melt during the final stages of magmatism.

Fig. 9. Well correlation, flattened on the base of the Upper Rattray, highlighting the two lithostratigraphic units of the RVM across the volcanic province. The Mid-Rattray volcanic hiatus is represented by a volcaniclastic sediment-dominated Pentland Formation layer interpreted between the Lower and Upper Rattray units in wells across the width of the province.

Fig. 10. Typical stratigraphic sequences drilled across the different areas of the Rattray Volcanic Province. Subaerial lavas and interbedded volcaniclastic sedimentary rocks are found throughout the majority of the volcanic province. Hyaloclastite appears to be confined to the NW and Central Areas. The RVM is typically unconformably overlain by Upper Jurassic or Cretaceous rocks due to footwall uplift and erosion during Late Jurassic rifting.

Fig. I I. Palaeogeographic evolution of the Rattray Volcanic Province. The timing of the different stages are relative; possible ages are suggested but the quality of the palynology data present in the Pentland Formation only indicate a broad Bajocian-Bathonian age to the whole sequence. Positions of some of the wells used to interpret each stage are highlighted as yellow dots.

Fig. I 2. Uplift and subsidence curve for the area of the Rattray Volcanic Province through the Jurassic Period. N.B. this is an approximation based on stratigraphic observations, not a numerical model. The presence of the lacustrine hyaloclastite at the base of the RVM indicates subsidence of the Rattray area of the North Sea dome began prior to volcanism, likely at a similar time as subsidence of the dome margins (Late Aalenian-Early Bajocian (Underhill \& Partington 1993)). 


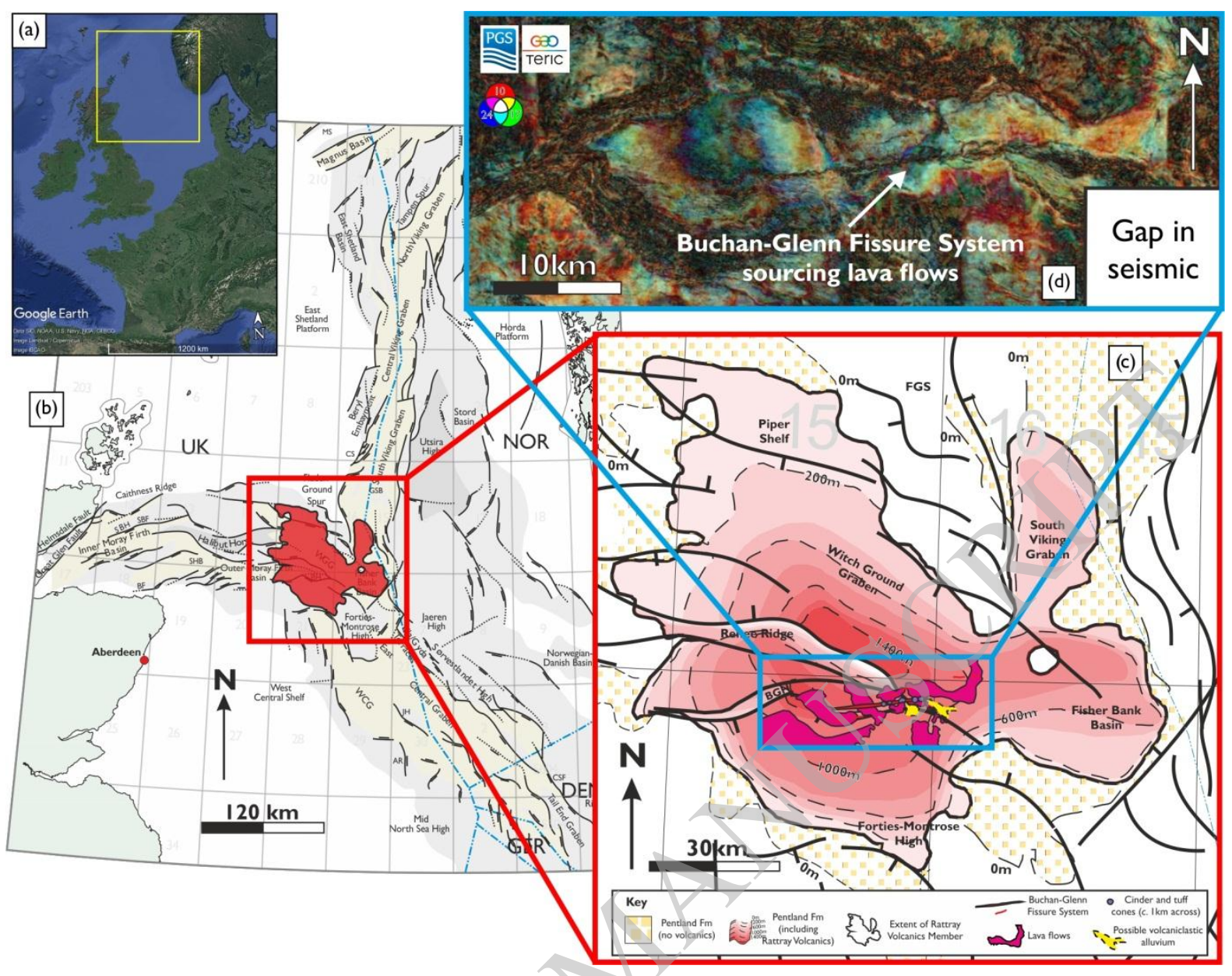




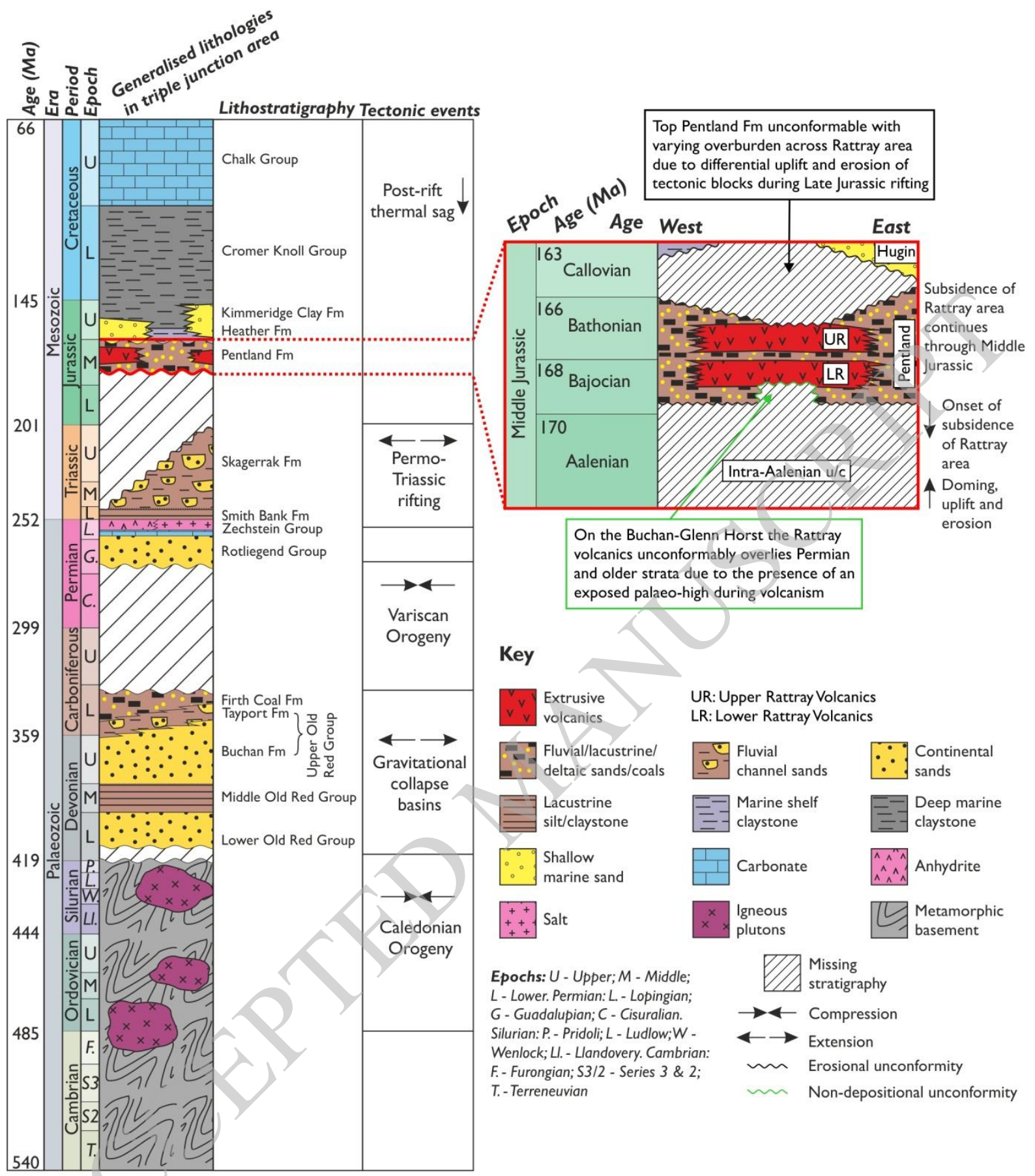




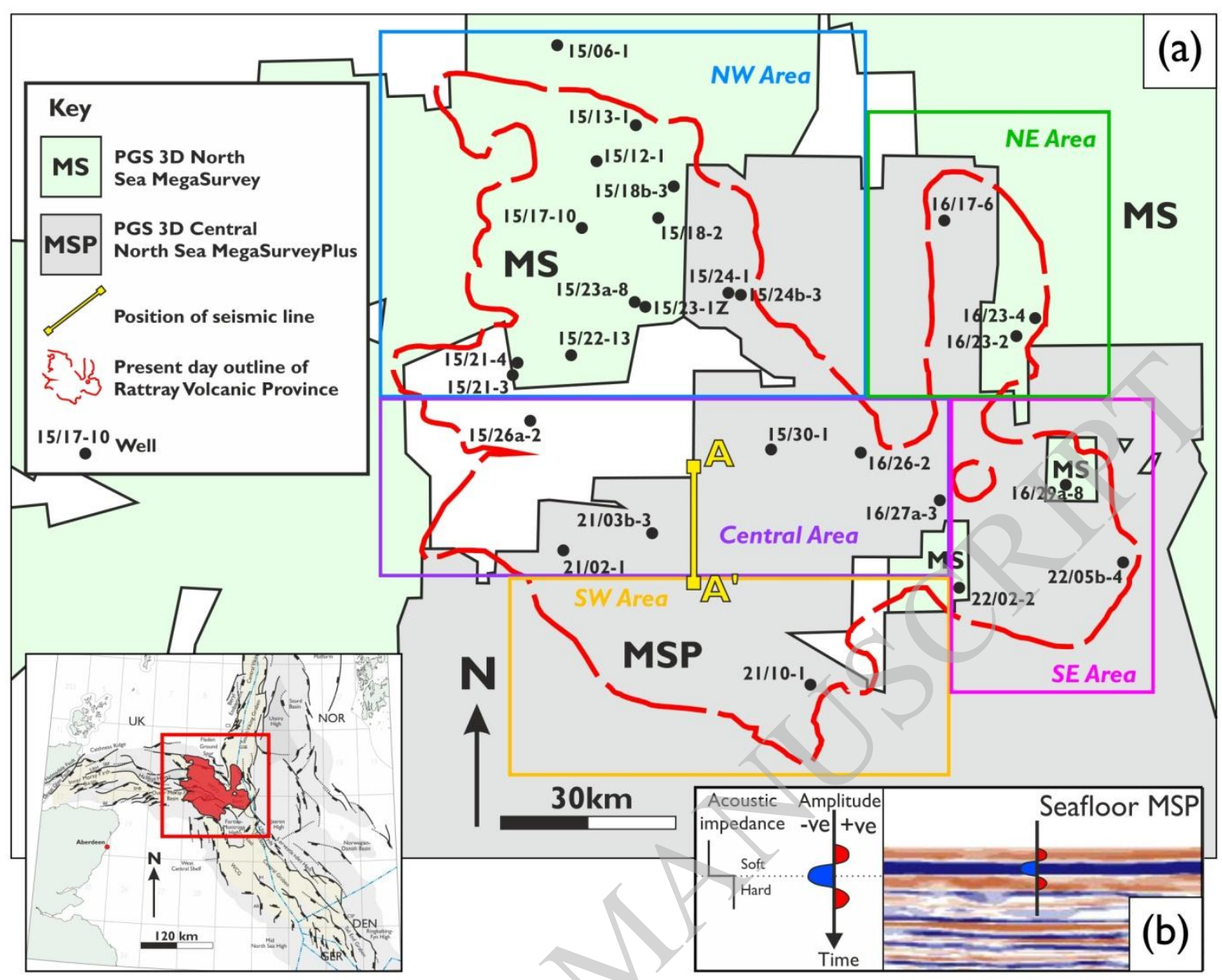




\section{Rattray Volcanics Member wireline igneous facies}

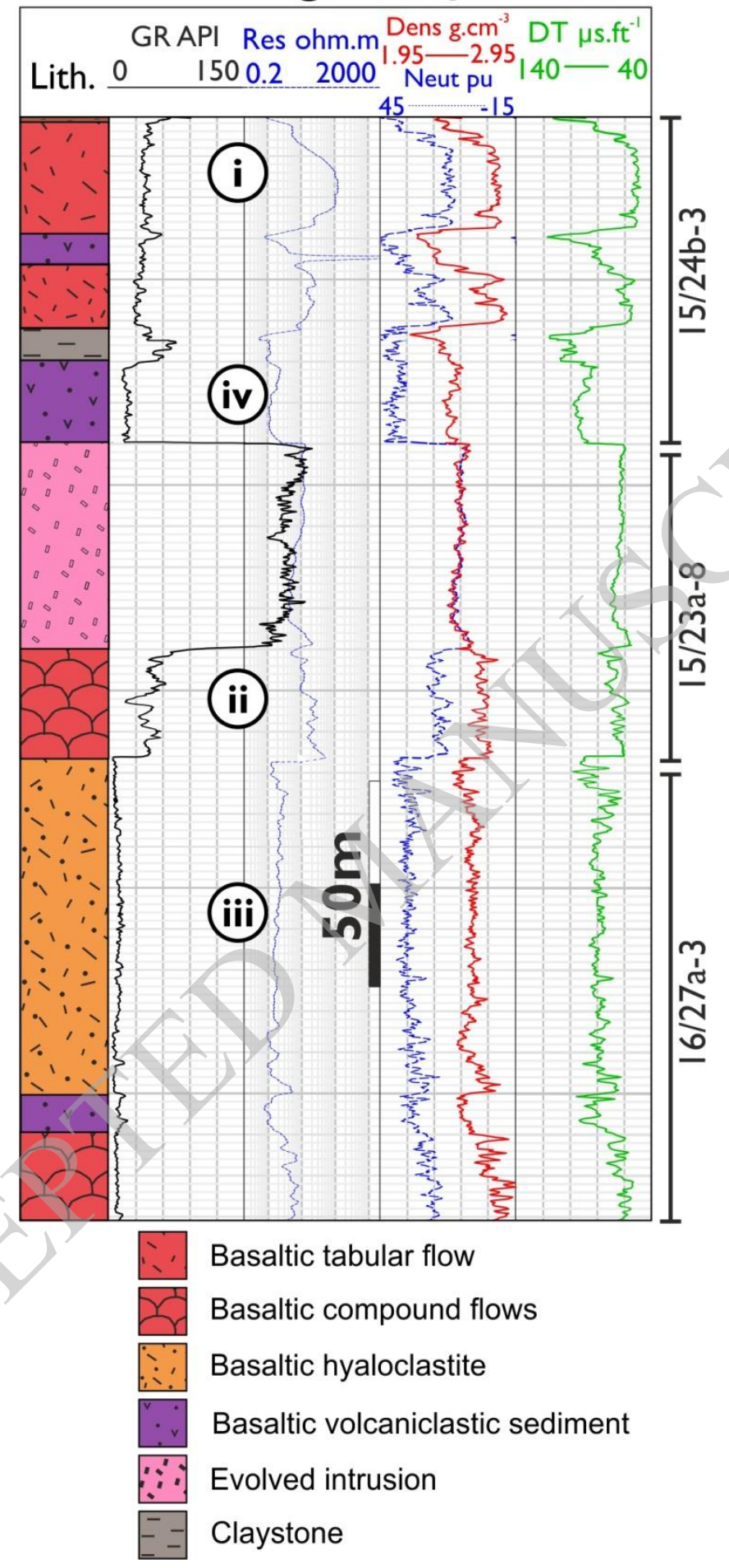




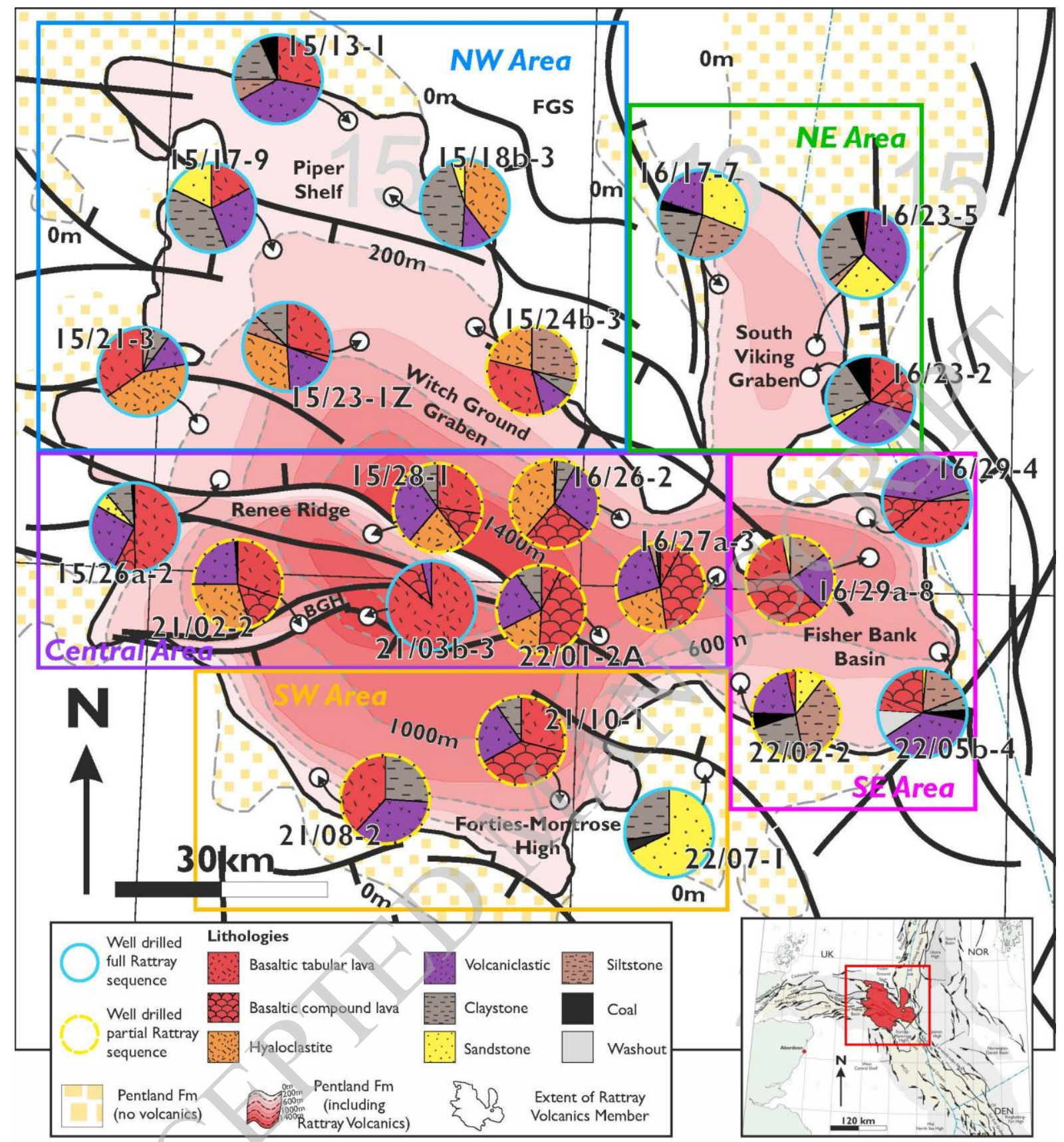




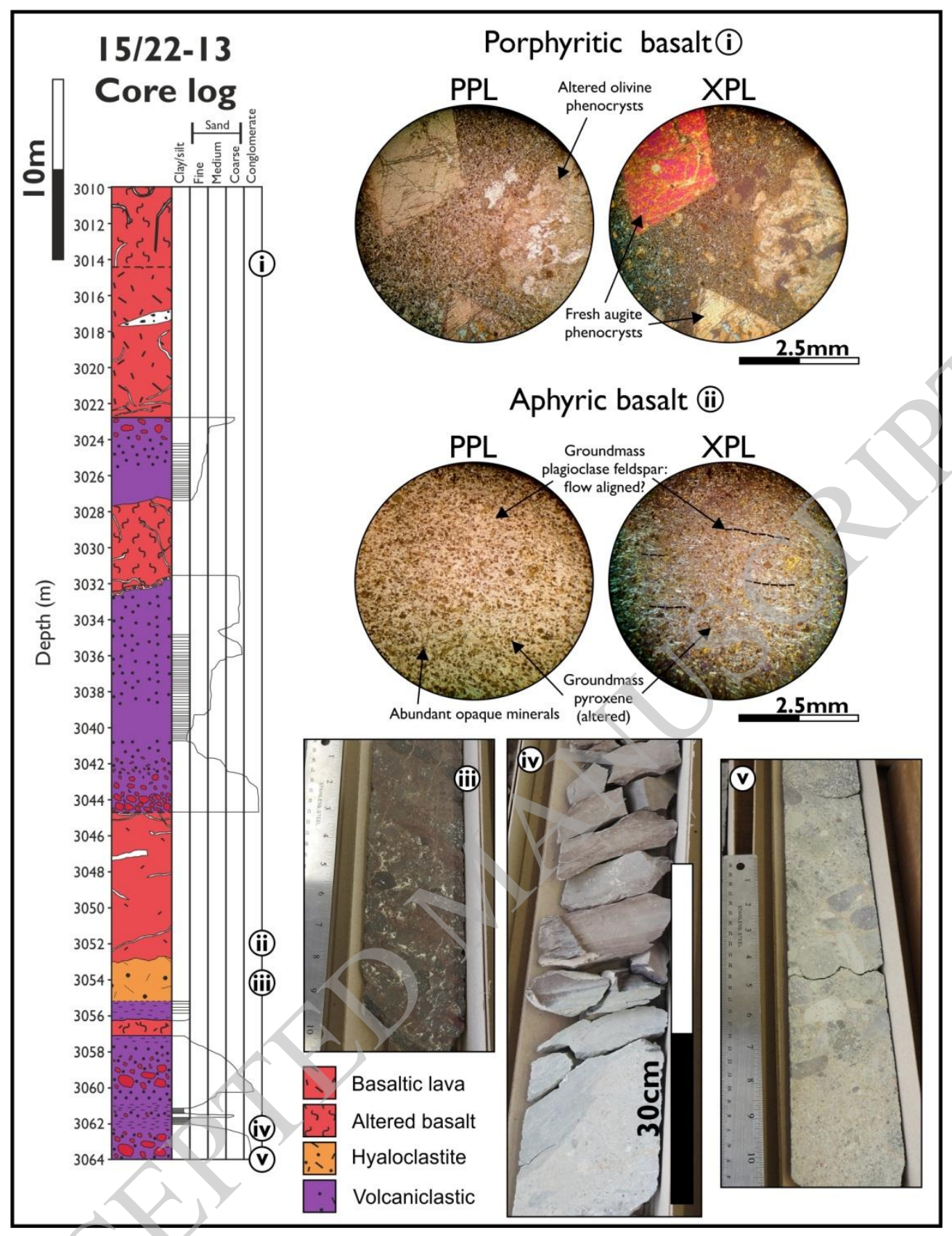


Downloaded from http://jgs.lyellcollection.org/ by guest on February 20, 2020

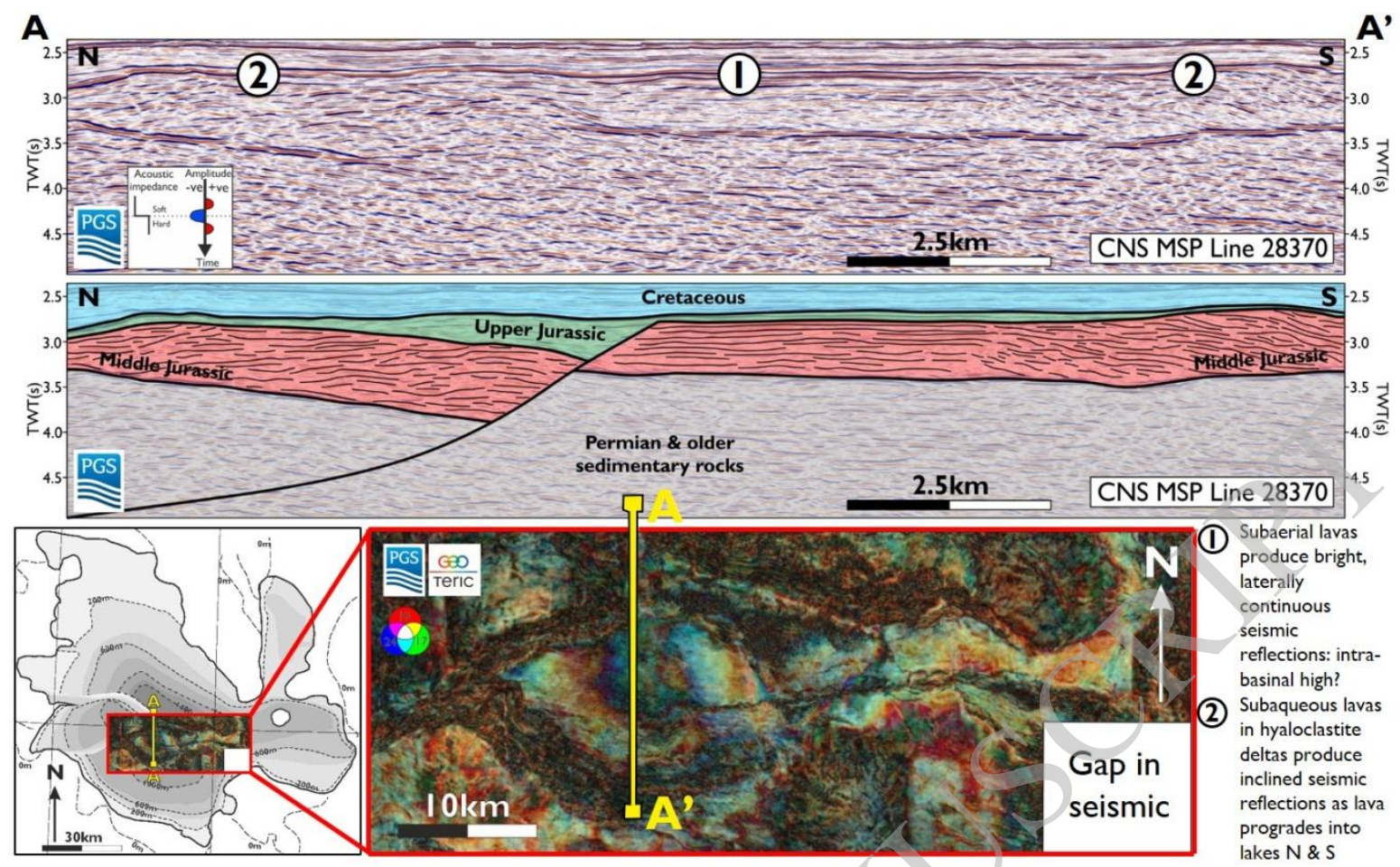




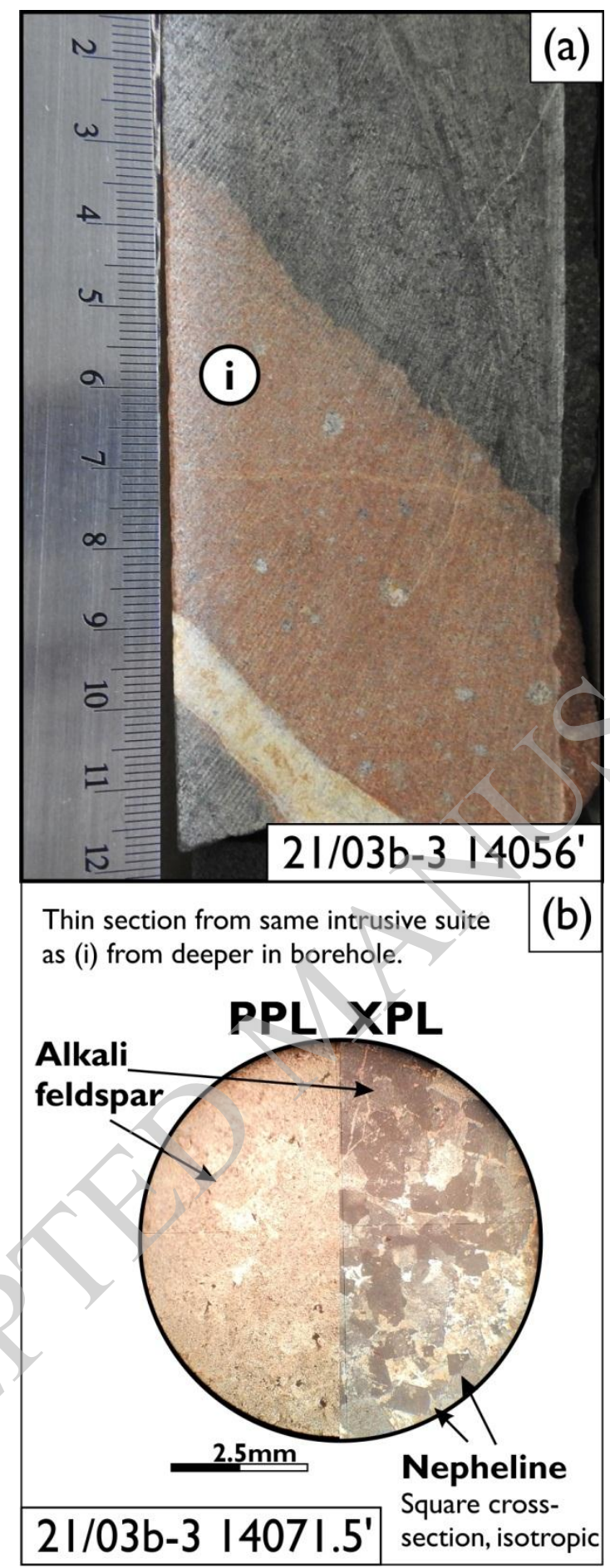




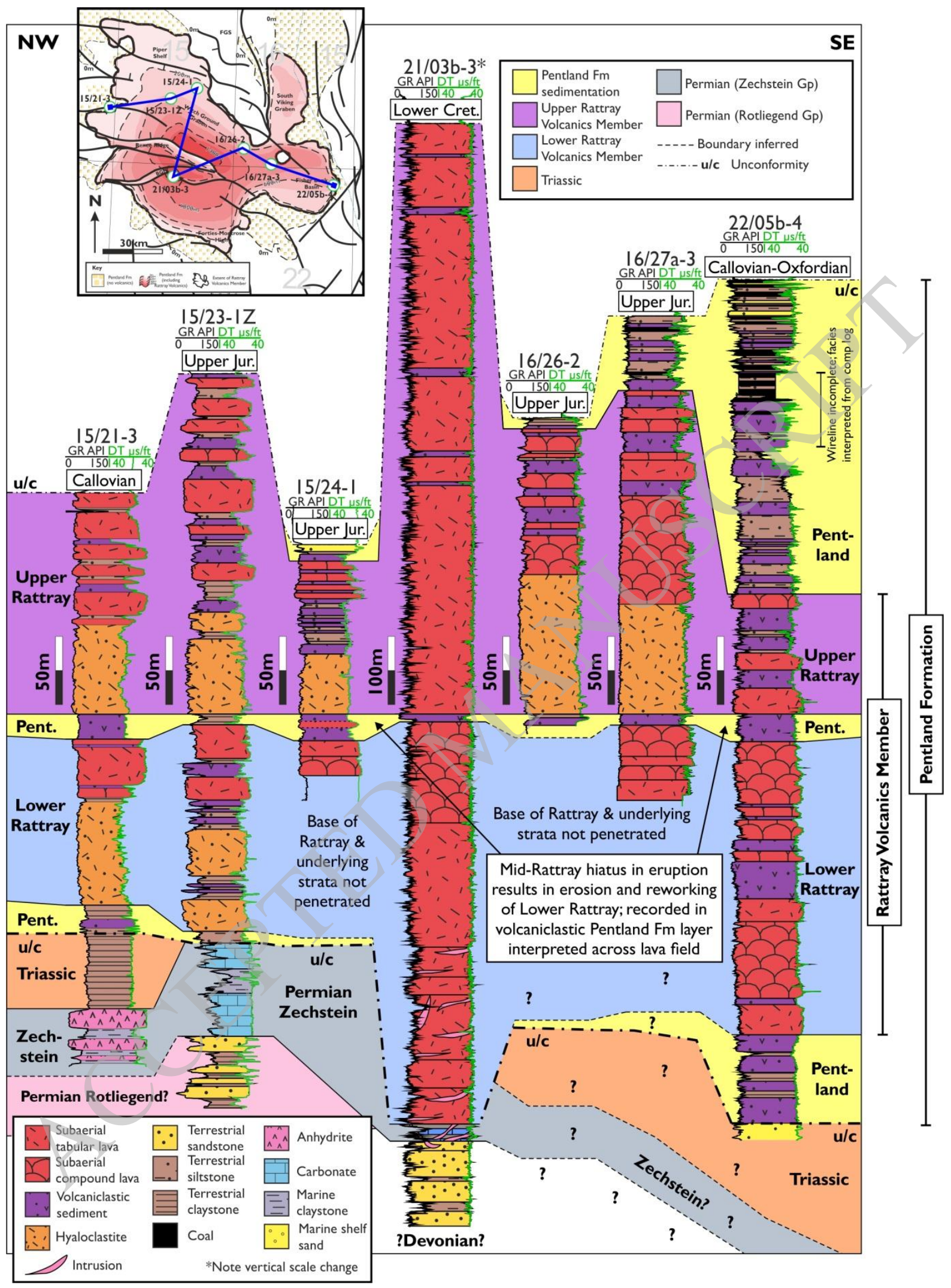


Downloaded from http://jgs.lyellcollection.org/ by guest on February 20, 2020

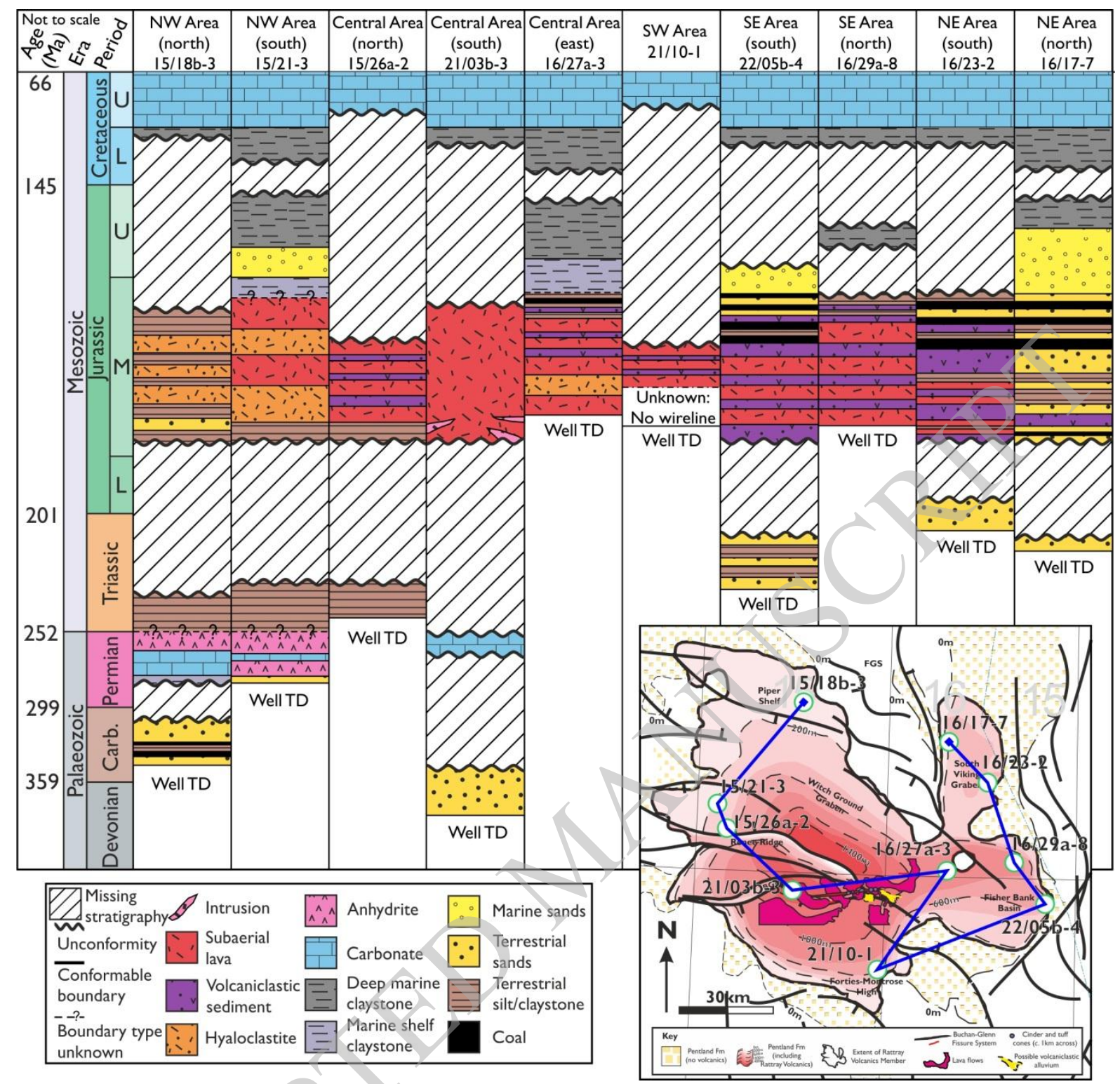




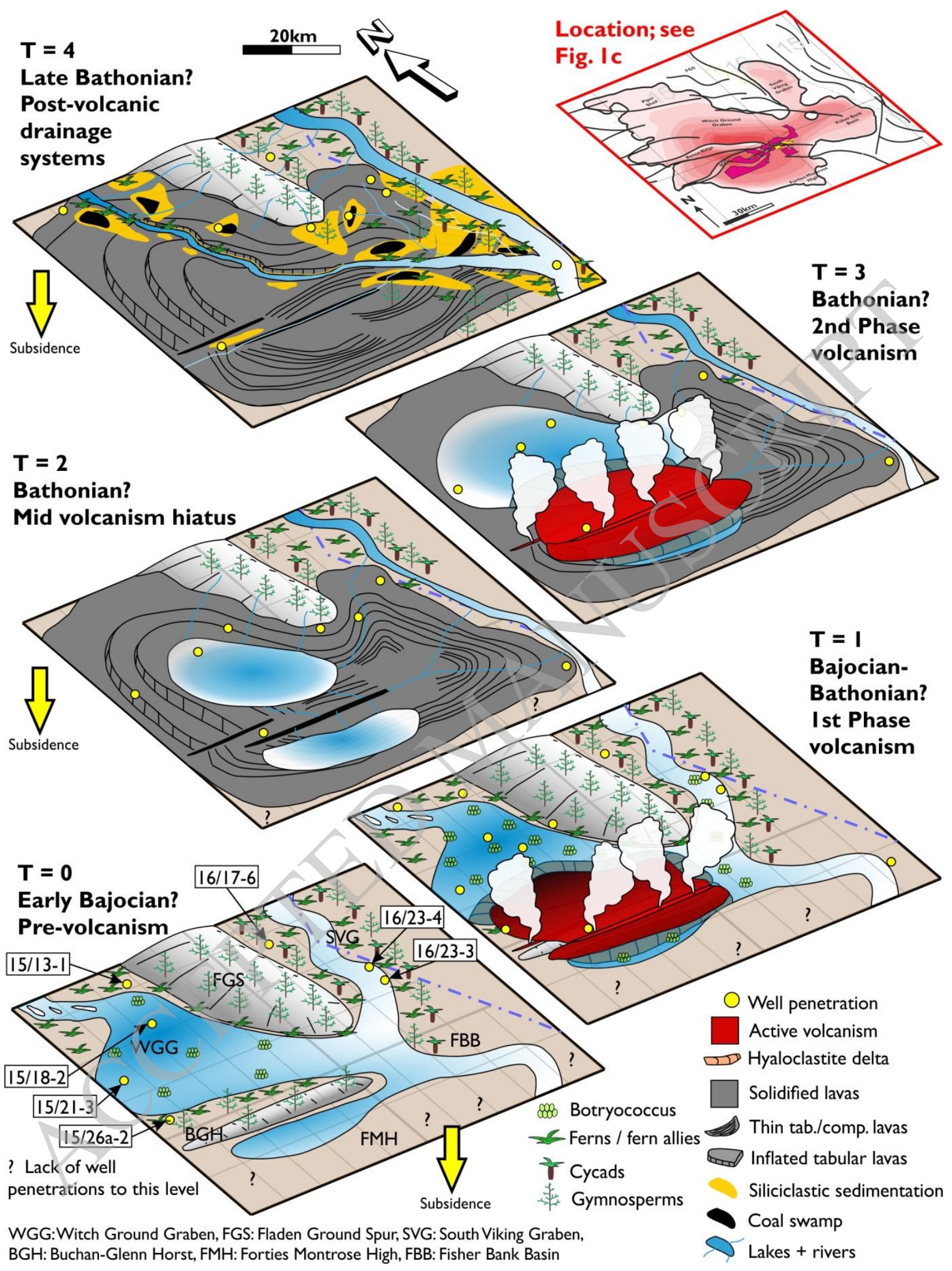




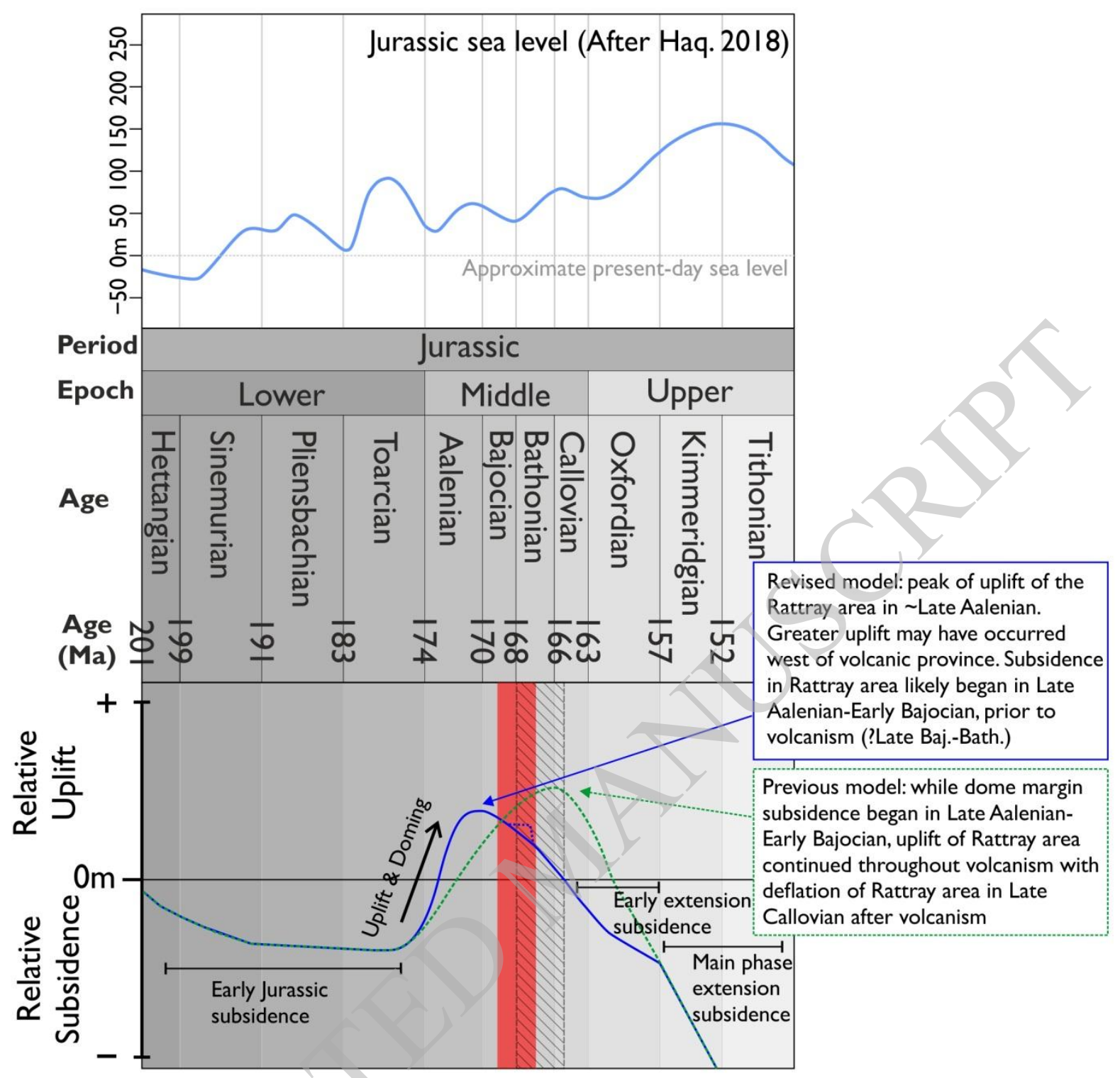

Approximate age of volcanism suggested in this study (Late Bajocian-Bathonian), absolute dates unknown Approximate age of volcanism suggested by Underhill \& Partington 1993 (Bathonian to Early Callovian) Approximate subsidence/uplift suggested in this study (possible subsidence was continuous — or pulsed ……..) Approximate subsidence/uplift suggested by Underhill \& Partington 1993 \& Fraser et al. 2002 
Downloaded from http://jgs.lyellcollection.org/ by guest on February 20, 2020

Table I. Areal subdivision of the Rattray Volcanic Province based on Upper Jurassic rift character.

\begin{tabular}{|l|l|}
\hline Area & Structural Elements \\
\hline NW Area & Northern Witch Ground Graben, Piper Shelf \\
\hline NE Area & South Viking Graben \\
\hline Central Area & Renee Ridge, Buchan-Glenn Horst, surrounding basinal areas \\
\hline SW Area & Forties-Montrose High \\
\hline SE Area & Fisher Bank Basin and surrounding terraces \\
\hline
\end{tabular}


Downloaded from http://jgs.lyellcollection.org/ by guest on February 20, 2020

Table 2. Total number of wells penetrating Rattray Volcanics Member in each area and percentage of wells in each area which penetrate the full volcanic succession.

\begin{tabular}{|l|l|l|l|l|}
\hline Area & $\begin{array}{l}\text { Number } \\
\text { of wells }\end{array}$ & $\begin{array}{l}\text { Percentage } \\
\text { of Rattray } \\
\text { wells }\end{array}$ & $\begin{array}{l}\text { Penetrates } \\
\text { full volcanic } \\
\text { succession }\end{array}$ & $\begin{array}{l}\text { Percentage of wells } \\
\text { penetrating full } \\
\text { volcanic succession }\end{array}$ \\
\hline Whole province & 235 & & $6 \mathrm{I}$ & $26 \%$ of Rattray wells \\
\hline NW & 148 & $63 \%$ & $4 I$ & $28 \%$ of NW wells \\
\hline NE & 12 & $5 \%$ & 8 & $67 \%$ of NE wells \\
\hline Central & 49 & $22 \%$ & 9 & $18 \%$ of Central wells \\
\hline SW & 16 & $6 \%$ & 0 & $0 \%$ of SW wells \\
\hline SE & 10 & $4 \%$ & 3 & $30 \%$ of SE wells \\
\hline
\end{tabular}


Table 3. Number of palynomorph, ostracods and foraminifera taxa recorded in the Pentland Formation well penetrations. Multiple sample numbers in one well represents palynology at different depths. Five representative wells from each area are shown here; complete palynological record is available in the supplementary material. Green boxes highlight Lowland Terrestrial group, purple highlights Aquatic group, blue indicates marine palynomorphs.

\begin{tabular}{|c|c|c|c|c|c|c|c|c|c|c|c|c|c|}
\hline \multirow[b]{2}{*}{ Area } & \multirow[b]{2}{*}{ Well } & \multirow[b]{2}{*}{$\begin{array}{l}\text { Sample } \\
\text { number }\end{array}$} & \multicolumn{7}{|c|}{ Terrestrial } & \multicolumn{2}{|c|}{ Aquatic } & \multicolumn{2}{|c|}{ Marine } \\
\hline & & & 迹 & 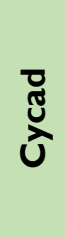 & $\begin{array}{l}\frac{\varepsilon}{d} \\
\frac{0}{0} \\
\frac{0}{0} \\
\frac{c}{\delta} \\
\text { ல }\end{array}$ & 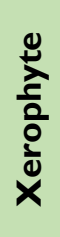 & 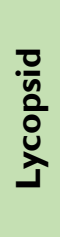 & $\frac{\stackrel{0}{d}}{\frac{1}{2}}$ & 둔 & $\begin{array}{l}\stackrel{0}{\mathbb{d}} \\
\frac{\infty}{4}\end{array}$ & 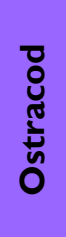 & 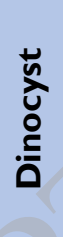 & $\frac{\text { ह }}{\frac{1}{0}}$ \\
\hline NW & $15 / 12-1$ & 201 & & & 2 & & & $I$ & 2 & & $\mathrm{I}$ & 1 & I \\
\hline NW & $|5 /| 2-1$ & 202 & & & & & & & I & & 2 & 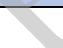 & \\
\hline NW & $15 / 17-10$ & 401 & & & I & & & & 2 & $\bar{T}$ & & 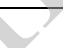 & \\
\hline NW & $15 / 17-25$ & 5901 & I & & 2 & & I & I & 3 & h & 5 & & \\
\hline NW & $15 / 18 b-3$ & 701 & & & 2 & & & & 2 & I & 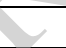 & & \\
\hline NW & $|5 / 2|-4$ & 6101 & & & 3 & I & I & 2 & 3 & $\mathrm{I}$ & & & \\
\hline NE & $16 / 17-6$ & 5003 & I & I & 3 & I & 2 & 2 & 5 & 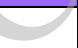 & & & \\
\hline $\mathrm{NE}$ & $16 / 17-9$ & 5101 & $\mathrm{I}$ & & 2 & & $\mathrm{I}$ & 2 & 5 & & & & \\
\hline NE & $16 / 18-1$ & 4903 & I & & 3 & & 1 & 1 & 2 & & & & \\
\hline NE & $16 / 23-3$ & $|40|$ & & & 3 & & & & I & & & & \\
\hline $\mathrm{NE}$ & $16 / 23-3$ & 1402 & & & & & 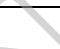 & $\sigma$ & & & & 5 & \\
\hline $\mathrm{NE}$ & $16 / 23-4$ & 4802 & I & & 2 & 1 & 1 & 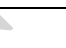 & 2 & & & & \\
\hline NE & $16 / 23-4$ & 4803 & I & & 2 & 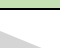 & $y$ & & 2 & & & & \\
\hline Central & $15 / 30-1$ & 2301 & I & & 3 & $z$ & 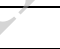 & & 2 & & & & \\
\hline Central & $15 / 30-3$ & 2401 & $\mathrm{I}$ & $\mathrm{I}$ & 1 & I & I & 2 & 4 & & & & \\
\hline Central & $16 / 26-3$ & 3401 & I & & & & & I & & & & & \\
\hline Central & I6/27A-3 & 3301 & I & & 1 & & & & 2 & & & & \\
\hline Central & I6/27A-3 & 3302 & 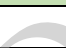 & & 1 & & & & 2 & & & & \\
\hline Central & $21 / 02-1$ & 903 & 1 & 1 & & & & I & I & & & & \\
\hline Central & $21 / 02-1$ & 904 & 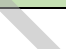 & & & & & & 2 & & & & \\
\hline SW & $21 / 04-2$ & 2501 & $1)$ & & 2 & I & & & 2 & & & & \\
\hline SW & $21 / 15 A-7$ & 3101 & 1 & & & & & I & $\mathrm{I}$ & & & & \\
\hline SW & $21 / 15 A-7$ & 3102 & & & 1 & & & & & & & & \\
\hline SE & I6/29A-8 & 2601 & & & 2 & & I & & 4 & & & & \\
\hline SE & $22 / 05 B-4$ & $100 \mid$ & I & & & & & I & 3 & & & & \\
\hline SE & $22 / 05 B-4$ & 1002 & & & I & & & & & & & & \\
\hline SE & $22 / 05 B-4$ & 1003 & & & & & & & & & & I & \\
\hline SE & 22/05B-9 & 1201 & I & & I & & & & 3 & & & & \\
\hline SE & 22/05B-I4 & 4101 & I & & 3 & I & 2 & 2 & 6 & & & & \\
\hline SE & $22 / 09-5$ & 3601 & I & & I & & I & & 2 & & & & \\
\hline SE & $22 / 09-5$ & 3602 & I & & & & & & & & & & \\
\hline
\end{tabular}

